Revista de Derecho

de la Pontificia Universidad Católica de Valparaíso

XXXII (Valparaíso, Chile, $1^{\text {er }}$ Semestre de 2009)

[pp. 39-106]

\title{
IDENTIDADES DE FUNCIONES O EFECTOS PROVENIENTES DE LA NEGOCIALIDAD ENTRE VIVOS Y POR CAUSA DE MUERTE*
}

["Identity of Functions or Effects Originating From the Ability to Negotiate inter vivos and mortis causa"]

\author{
Alejandro Guzmán Brito** \\ Pontificia Universidad Católica de Valparaíso
}

\begin{abstract}
RESUMEN
Sobre la base de reconocer que al menos hay dos métodos para analizar las figuras del Derecho, uno que atiende a sus estructuras y otro a sus funciones, en aplicación de este último el presente artículo verifica la existencia de un paralelismo de funciones que pueden tener lugar tanto entre vivos, aunque por lo general merced a estructuras contractuales, como por causa de muerte por medio a estructuras legatarias; de modo que diversas estructuras pueden cumplir, en su orden, las mismas funciones: la constitución de derechos reales y de derechos personales, la circulación del dominio de las cosas corporales, la circulación de derechos reales y de derechos personales, la extinción de derecho reales, la tipologización de las obligaciones, la
\end{abstract}

\begin{abstract}
Based on the fact that there are at least two methods to analyse concepts of Law, one of which deals with its structures, and the other one with its functions, in the application of the latter, this article verifies a parallelism of functions that can take place inter vivos, albeit in general, thanks to contractual structures, as mortis causa, by means of legatee structures; thus, several structures can comply with it, in turn, with the same functions: the constitution of in rem rights and personal law, circulation of the dominion of corporeal things, circulation in rem rights and personal law, the extinction of in rem rights, characterization of obligations, characterization of the effects of the obligations, possibility of payment, remission, compensation and confusion
\end{abstract}

* Este trabajo hace parte del proyecto Fondecyt N 1070432, de 2007.

** Catedrático de Derecho romano en la Facultad de Derecho de la Pontificia Universidad Católica de Valparaíso. Dirección postal: Facultad de Derecho, Pontificia Universidad Católica de Valparaíso, Avenida Brasil 2950, Valparaíso, Chile. Correo electrónico: aguzman@ucv.cl 
tipologización de los efectos de las obligaciones, la posibilidad de pago, remisión, compensación y confusión entre vivos y por causa de muerte.

Palabras Clave: Función - Estructura - Funciones de los legados - Funciones de los contratos - Funciones entre vivos - Funciones por causa de muerte. inter vivos and for mortis causa.

KEYwords Function - Structure Functions of the legacies - Functions of the contracts - Inter vivos functions - Mortis causa functions.

\section{ESTRUCTURA Y FUNCIÓN EN LAS FIGURAS JURÍDICAS}

1. La exposición dogmático-sistemática del Derecho contenido en el Código Civil puede ser conducida, quizá entre otros, sobre la base de un criterio estructural o de uno funcional. Por lo demás, ambas posibilidades son recurridas por el Código Civil mismo; y lo propio cabe decir de los demás códigos y de muchas leyes de denso contenido dogmático.

El primer criterio consiste en observar los actos y hechos jurídicos con el propósito de verificar la existencia de estructuras iguales o desiguales en ellos, para enseguida clasificarlos y exponer sus regímenes en lugares sistemáticos apropiadamente creados en consonancia con aquéllas. Característicos de un modo de proceder así son los resultados que se alcanzan, por ejemplo, al exponer las fuentes de las obligaciones sobre la base de su estructura contractual, que luego, según el modo de ser diferente de tal, son subclasificados como reales, consensuales y solemnes; o bien la institución de heredero y los legados a partir de la estructura testamentaria común. El criterio funcional, en cambio, observa la igualdad o semejanza de los efectos de un acto o hecho jurídicos, los clasifica y ordena de acuerdo con ellos y construye los lugares sistemáticos de exposición basados en los mismos; como acaece, por ejemplo, cuando se estudia los modos de extinguir obligaciones, de los que no se toma en cuenta las diferentes estructuras existentes entre ellos (v.gr., si son convencionales o no lo son, etcétera), pues únicamente se atiende al efecto precisamente extintivo.

El uso unilateral de estos criterios conduce a una recíproca exclusión. Cuando los actos y hechos son estudiados según sus uniformidades estructurales, sin atención principal a sus funciones, se pasan por alto tanto la homogeneidad, cuanto la heterogeneidad de éstas; $y$, al revés, si únicamente se presta atención a las uniformidades funcionales, ahora lo desatendido son la homogeneidad y la heterogeneidad de las estructuras de que derivan las funciones verificadas. Que debido a la estructura real del mutuo y del depósito vayan ambos situados en un único rango sistemático, eso esconde las profundas diversidades, aunque también las leves 
similitudes funcionales que los afectan; si, en cambio, por causa de sus diversas estructuras se separa el tratamiento de la tradición y el legado de efectos reales, ahora lo ocultado son sus profundas similitudes y también sus diferencias funcionales. De lo que se concluye que el estudio integral de los actos y hechos jurídicos debe combinar ambos criterios, como manera eficaz de penetrar en sus esencias y relaciones más recónditas.

2. En principio, el Código Civil adopta el criterio estructural; pero recurre esparcida y asistemáticamente al funcional.

Así, su clasificación de las fuentes de obligaciones constituidas por actos o hechos, en contratos, cuasicontratos, delitos y cuasidelitos es puramente estructural. Eso deja en la penumbra las homogeneidades que hay entre, por ejemplo, la gestión de negocio ajeno, la tutela y el mandato civil, de las cuales la primera es la noción básica y general; la segunda, una especialización de aquélla fundada en el objeto y en la constitución; y el tercero, una modificación general derivada de su estructura convencional; del que además provienen los distintos tipos especiales de mandato comercial.

Pero en materia de modos de extinguir obligaciones, en cambio, el Código adopta el criterio predominantemente funcional, porque trata del efecto extintivo, proceda de la estructura de que proceda. Las normas del $\$ 1$ del título $14^{\circ}$ del libro IV, sobre el pago, por ejemplo, se aplican a las obligaciones provenientes de cualquier fuente, no bien en ocasiones ello quede en el olvido y se las exponga como exclusivamente aplicables a las obligaciones convencionales. Algo semejante ocurre con la compensación tratada en el título $17^{\circ}$ del mismo libro. Lo cual, por lo demás, puede ser verificado en muchos casos, que no indagaremos, por no ser tal el objeto del presente trabajo.

3. Ahora bien, en donde se observa muy bien la separación de los criterios estructural y funcional es en materia de actos y efectos entre vivos y por causa de muerte. En lo inmediato, ello se debe a la reserva del libro III exclusivamente para estos últimos, entre los cuales quedan insertados los legados, de modo que implícitamente los libros II y IV aparecen como si estuvieran referidos nada más que a los actos y efectos entre vivos; cuando no es así.

Este es el ámbito en el que se concentra el presente estudio, que ha de ser preponderantemente conducido sobre la base del criterio funcional, con el propósito de poner en evidencia la similitud precisamente de funciones de que son capaces ciertos actos entre vivos, y de manera especial las convenciones, y los legados, pese a sus tan notables diferencias estructurales. Las funciones que aquí tomaremos en cuenta son: la constitución de derechos reales (II) y de derechos personales (III), la circulación del dominio de las cosas corporales (IV), la circulación de derechos reales (V) y de derechos 
personales (VI), la extinción de derecho reales (VII), la tipologización de las obligaciones (VIII), la tipologización de los efectos de las obligaciones (IX), y la posibilidad de pago, remisión, compensación y confusión entre vivos y por causa de muerte (X). En un primer apéndice examinaremos la posibilidad de extender las normas de interpretación del contrato al testamento (XI); y en un segundo apéndice, algunos paralelismo funcionales en actos del Derecho de personas y de la familia que, por lo que atañe a estos últimos, no son propiamente legados (XII). Finalizará el trabajo con una breve síntesis (XIII).

\section{CONSTITUCIÓN VOLUNTARIA DEL CUASIDOMINIO DE DERECHOS REALES COMO ESPECIE DE LAS COSAS INCORPORALES, ENTRE VIVOS MEDIANTE TRADICIÓN O INSCRIPCIÓN Y POR CAUSA DE MUERTE MERCED A LEGADOS}

1. Este capítulo no es el correlativo de otro concerniente a las cosas corporales. No decimos, en efecto, que ellas se constituyan alguna vez, pues, ora preexisten in rerum natura, ora son fabricadas por el hombre a partir de aquéllas o de otras también prefabricadas por él mismo. La existencia dada y la fabricación, consideradas en sí, son hechos, aunque en algunos casos adquieran carácter jurídico, como en la especificación o en el contrato de arrendamiento para la confección de una obra material o en el mandato. Las cosas incorporales, en cambio, no existen in rerum natura, y necesariamente deben ser inicialmente constituidas, es decir, creadas merced a un acto o un efecto jurídico (o la ley), si bien, a veces, el acto jurídico puede tener por base un hecho, como en los delitos y cuasidelitos $\mathrm{u}$, ocasionalmente, en la agencia oficiosa y en otros casos.

En este capítulo nos referiremos, pues, a la constitución, o creación, voluntaria de aquella especie de cosas incorporales denominada "derecho real” mediante sendos actos paralelos, como son la tradición, entre vivos, y el legado de efectos reales, por causa de muerte. Ambos generan un "cuasidominio" sobre el derecho, como denominamos a la "especie de propiedad" que sobre las cosas incorporales dice existir el artículo 583 CC., y que, en otro lenguaje, podemos identificar con su titularidad ${ }^{1}$. Mirado este efecto desde el punto de vista del beneficiario del derecho, para él hay una adquisición; así que, desde ese punto de vista, la tradición y el legado constitutivos de derechos reales nuevos actúan como modos de adquirir tales derechos.

\footnotetext{
${ }^{1}$ Sobre esto, véase: GuzMán Brito, Alejandro, Las cosas incorporales en la doctrina y en el Derecho positivo (2a edición, Santiago, Editorial Jurídica de Chile, 2006), pp. 119 ss.
} 
2. Entre vivos, la constitución voluntaria de derechos reales nuevos ${ }^{2}$ está sometida a un régimen variado.

a) Los derechos reales de usufructo (artículos $766 \mathrm{~N}^{\circ} 3,670$ inciso $2^{\circ}$ y 686 inciso $2^{\circ}$ CC.) y uso (artículo 812 que reenvía a los citados precedentemente) inmuebles, y de habitación (artículo 812 que reenvía a los concernientes al usufructo ya citados), de hipoteca civil (artículos 2409, 670 inciso $2^{\circ}, 686$ inciso $2^{\circ}$ y 2410 CC.), de servidumbre de alcantarillado en predios urbanos (artículo 1 L. N ${ }^{\circ} 6.977$, DO. 16 jul. 1941) y de censo (artículos 2023, 2027 y 686 inciso $2^{\circ}$ CC.), que, por su objeto, son siempre inmuebles, se constituyen merced a la inscripción del título oneroso o gratuito de la constitución (que, por ende, debe constar en una escritura pública), en el Registro de Hipotecas y Gravámenes del Conservador de Bienes Raíces. Los derechos de servidumbre civiles que no sean de alcantarillado en predios urbanos, se constituyen, sobre la base de un título gratuito u oneroso, que debe constar en escritura pública ${ }^{3}$, mediante el consenso del constituyente y del adquirente en orden a la constitución, que también debe constar en escritura pública, la cual no es necesario inscribir (artículos 882 y 698 CC., con el añadido de que el título y la constitución pueden contar en una misma escritura). A este mismo régimen se somete la constitución de las servidumbres mineras (artículo 92 inciso $3^{\circ}$ y 123 CM.) y las de aguas (artículo 108 C. de A.). La hipoteca naval se constituye, sobre la base de un título que conste en escritura pública, por su inscripción en el Registro de Hipotecas, Gravámenes y Prohibiciones de la Dirección General del Territorio Marítimo y de Marina Mercante (artículos 868 y 871 C. de C.).

Los derechos de usufructo y uso muebles se constituyen, sobre la base de un título oneroso o gratuito, que puede ser consensual, merced a la entrega de la cosa por el constituyente al usufructuario o usuario (artículos 670 inciso $2^{\circ}$ y 684 CC.).

El derecho de prenda civil con desplazamiento se constituye, sobre la base del consenso entre un acreedor y su deudor o un tercero, en orden a afectar una cosa corporal mueble al cumplimiento de cierta obligación, mediante la entrega de la misma cosa por el que corresponda de los dos últimamente mencionados al acreedor (artículo 2386 CC.). De acuerdo

${ }^{2}$ Nos referimos, por cierto, a la constitución de derechos reales en concreto nuevos, aunque pertenecientes al género de los ya en abstracto descritos en la ley. No se trata aquí de la posibilidad de crear un tipo nuevo de tales derechos, que en virtud del principio de tipificación legal que los rige, no es posible.

${ }^{3}$ Salvo si el título consiste en el reconocimiento expreso del dueńo del predio sirviente o en la destinación anterior hecha conforme con el artículo 881 CC. (artículo 883 CC.). 
con el artículo 25 del artículo 14 de la Ley No 20.190 (DO. 5 jun. de 2007), el derecho real de prenda sin desplazamiento se constituye por medio de la inscripción del contrato en el Registro de Prenda sin Desplazamiento -el cual contrato debe otorgarse en escritura pública o en instrumento privado (las firmas de cuyos comparecientes han de ser autorizadas por un notario) protocolizado en el registro del notario autorizante (artículo 2 de la ley citada)-.

El derecho real de patente (llamado a veces "propiedad industrial") se adquiere mediante un acto administrativo del Departamento de Propiedad Industrial, llamado "título de protección" (artículo 2 L. No 19.039).

b) Ahora bien, para el Código, estas diversidades de constitución obedecen a una única manera, que es la tradición. Su artículo 670, después de definir ese modo en el inciso $1^{\circ}$, y hacerlo consistir esencialmente en una "entrega", añade en el $2^{\circ}$ : "Lo que se dice del dominio se extiende a todos los otros derechos reales". Y su artículo 686, que en el inciso $1^{\circ}$ define la manera de operar la tradición del dominio de los bienes raíces, que consiste, no ya en una entrega, sino en una inscripción, agrega en el inciso $2^{\circ}$ : "De la misma manera se efectuará la tradición de los derechos de usufructo o de uso constituidos en bienes raices, de los derechos de habitación o de censo y del derecho de hipoteca". El inciso $2^{\circ}$ del artículo 670 CC., antes transcrito, pues, determina una regla general sobre tradición de derechos reales consistente en una entrega. El inciso $2^{\circ}$ del artículo 686 CC., aunque sigue la regla general, en lo relativo a necesitarse una tradición, la especializa en cuanto al modo de practicarla cuando de derechos reales inmuebles se trata. De lo que se sigue-como siempre se ha entendido-que la tradición mediante entrega prevista por el inciso $2^{\circ}$ del artículo 670 CC. vale para los derechos reales muebles, bajo la idea de que lo entregado no es el derecho real mismo -que por su incorporeidad no puede ser entregado-, sino la cosa mueble en que recae, única que, por la razón contraria, puede ser entregada, atendida la naturaleza material o física de este último acto, por lo demás regulado en el $\$ 2$ : De la tradición de las cosas corporales muebles, del título $6^{\circ}$ del libro II CC., si bien deba subentenderse en su rúbrica y articulado lo antes dicho, relativamente a su extensión a los derechos reales muebles.

De esta manera, en el Código Civil menester es distinguir conceptual aunque no realmente, la tradición-inscripción en función constitutiva de la tradición-inscripción en función traslaticia, a que nos referiremos después.

En otros cuerpos legales, empero, se tiende a distinguir ambas nociones realmente. Así, por ejemplo, el artículo 117 del Código de Aguas diferencia la tradición en su inciso $1^{\mathrm{a}}$, y la constitución en su inciso $2^{\mathrm{a}}$, aunque 
ambas consistan en una inscripción; algo semejante acaece en el Código de Minería, cuyo artículo 92 también separa ambos conceptos.

c) Con todo, hay excepciones.

i) El derecho real de herencia no se constituye por tradición-inscripción, sino mediante sucesión por causa de muerte. La razón depende de la general prohibición de actos sobre sucesión futura (artículos 1463 y 1204 inciso $2^{\circ} \mathrm{CC}$.), pues una tradición constitutiva de aquel derecho necesariamente sería un acto así. De paso - porque no se trata de nuestro actual temarecordemos que un derecho real de herencia ya constituido por sucesión, empero, puede ser transferido entre vivos por tradición (cesión: artículos 1909 y 1910 CC.); y ello para explicar la general dicción del artículo 670 inciso $2^{\circ}$ CC., en orden a que lo dicho para el dominio se extiende " $a$ todos" los otros derechos reales, con inclusión, por ende, del derecho de que hablamos; dicción que, en consecuencia, debe entenderse referida a él en cuanto ahí se implica la tradición en función traslativa; pero no en cuanto también se mienta la tradición en función constitutiva; al revés de cuanto acaece para los demás derechos reales, respecto de los cuales la tradición ahí referida va considerada en ambas funciones. También explica la omisión del derecho real de herencia en el elenco de derechos de tal naturaleza mencionados en el inciso $2^{\circ}$ del artículo 686 CC., pues para aquél no pudo preverse una inscripción constitutiva.

ii) Los derechos reales mineros de pedimento y manifestación y de concesión de exploración y de explotación se constituyen por sentencia judicial, que no necesariamente debe ser inscrita más que para adquirir su cuasiposesión (artículo 91 C. de M.). Los derechos reales de aprovechamiento de aguas se constituyen por acto de autoridad, cuya inscripción también es sólo necesaria para adquirir la cuasiposesión de tales derechos (artículo 20 inciso $1^{\text {a }}$ CA.). Los derechos reales de autoría (moral) y de autor (patrimonial) se constituyen por un modo especial denominado "creación de la obra" (artículo 1 L. No 17.336).

iii) En algunos casos, la causa de constitución del derecho es la ley. Tal acaece, por ejemplo, con el "derecho legal de goce" que confiere la patria potestad sobre los bienes del hijo, con algunas excepciones, definido por el artículo 252 inciso $1^{\circ} \mathrm{CC}$., y también denominado "usufructo legal del padre o la madre" por el inciso final del mismo artículo. Otro ejemplo es la hipoteca constituida por el artículo 662 CPC. sobre los bienes raíces adjudicados en una partición, para garantizar el pago de los alcances; y desde luego en todos los casos de servidumbres legales ( $\$ 2$ del título $11^{\text {a }}$ del libro II CC.; letras c) a g) del párrafo 1 del título $7^{\text {a }}$ del libro I CA.).

d) Cuando la tradición de un derecho real (o la sucesión en el caso del derecho real de herencia) no pudo operar su función constitutiva del 
respectivo derecho de manera normal, debido a algún vicio que lo afectó, en sustitución puede intervenir la prescripción adquisitiva en la misma función. La regla general en tal sentido está dada en el inciso $2^{\circ}$ del artículo 2512 CC.; pero se reitera la prescriptibilidad de varios de los derechos singulares en sus respectivas sedes materiae $e^{4}$.

Ahora bien, si dejamos a un lado la ley y el acto judicial o de autoridad, como modo excepcionales de constituir algunos derechos reales, y la prescripción, que no es excepcional, pero sí subsidiaria, como remedio que es, resulta que la manera normal de constituir entre vivos un derecho real es, pues, la tradición-inscripción de los derechos civiles inmuebles, o la tradición de los muebles, o la inscripción de los especiales.

3. Salvo, sin discusión, aquellos derechos reales que se constituyen sólo por acto administrativo o judicial, y los derechos reales de herencia y de autor y autoría, en principio todos los demás pueden ser constituidos o creados por un legado. La regla general viene establecida en el artículo 1127 inciso $1^{\circ}$ CC.: "Pueden legarse [...] los derechos y acciones". En la expresión "los derechos" van incluidos, por cierto, los derechos reales. La disposición, en realidad, abraza dos situaciones diferentes: por un lado, la dicha, de poderse crear derechos reales nuevos mediante legado; por otro, la de poderse transmitir tales derechos por el mismo medio. Aquí nos interesa la primera. La cual viene especificada en muchos casos para derechos singulares.

Se dice expresamente así, en efecto, para el usufructo (artículo $766 \mathrm{~N}^{\circ}$ 2: "por testamento"), uso y habitación (artículo 812, que también reenvía al antes citado) y censo (artículo 2023 CC.: "por testamento"). Nada se dice para las servidumbres voluntarias civiles, de aguas y mineras; pero es claro que ellas se pueden constituir mediante un legado de efectos reales, de acuerdo con la regla general sentada por el artículo 1127 inciso $1^{\circ} \mathrm{CC}$.; como cuando el testador dice: "Lego a Ticio una servidumbre de paso en favor de su fundo Corneliano sobre mi fundo Capeno".

Con respecto al derecho real de hipoteca, no está prevista la posibilidad de constituirlo mediante legado. En teoría, ello no resulta estructural ni funcionalmente imposible. Alguien podría, en efecto, disponer en su testamento así: "Para garantizar tal deuda de Ticio para con Cayo, constituyo hipoteca sobre mi fundo Corneliano a favor de Cayo"; o bien: "Ordeno que

${ }^{4}$ Código Civil, artículos 766 № 4 (usufructo), 812 (que, para los derechos de uso y habitación, se remite a los modos de constitución del usufructo), 882 (al cual se remite el artículo $2512 \mathrm{~N}^{\circ} 2 \mathrm{CC}$., en materia de servidumbres continuas y aparentes), $2512 \mathrm{~N}^{\circ} 1$ (herencia y censo, mencionados como excepción a la regla general, pero sólo en cuanto al plazo de prescripción); $93 \mathrm{CM}$. (concesiones mineras), $21 \mathrm{CA}$. (derechos de aprovechamiento de aguas). 
mi legatario Ticio conceda un crédito de 1.000 a Cayo y para garantizar este crédito, constituyo hipoteca sobre mi fundo Corneliano a favor de Ticio". De hecho, sin embargo, hay impedimentos exegéticos. Aun dejando a un lado que la hipoteca está considerada como un contrato en el Código Civil, el artículo 2409 CC. exige escritura pública para la constitución de ese derecho, y un testamento, aún el más solemne, no es escritura pública, aunque, si cumple con sus requisitos, podría considerársela tal. Con respecto a la prenda con desplazamiento, como un testamento es incompatible con una entrega, no se la podría constituir mediante aquél. En lo concerniente a la prenda con desplazamiento, la discusión es semejante a aquélla de la hipoteca.

4. En conclusión, puede verificarse que en el interior del sistema creado por el Código Civily seguido por los códigos y leyes especiales que contienen Derecho civil, hay dos regímenes normales y generales de constituir voluntariamente derechos reales nuevos: uno, entre vivos, es el de la tradición, tradición-inscripción o inscripción; y el otro, por causa de causa, el del legado de efectos reales. La tradición y el legado en función constitutiva de derechos reales nuevos son, pues, los ejes paralelos de aquel sistema.

\section{CONSTITUCIÓN VOLUNTARIA DEL CUASIDOMINIO DE DERECHOS PERSONALES COMO ESPECIE DE LAS COSAS INCORPORALES ENTRE VIVOS MEDIANTE CONTRATO Y POR CAUSA DE MUERTE MERCED A LEGADOS}

1. La constitución de derechos personales como especie de cosas incorporales es una manera de describir lo que habitualmente denominamos sintéticamente "fuentes" de las obligaciones. Éstas, en efecto, las "constituyen" y hacen nacer un cuasidominio sobre el derecho. El Código Civil conoce cinco tipos de estas fuentes: contrato, cuasicontrato, delito, cuasidelito y ley (artículos 1437 y 2228 CC.).

En este conjunto, el contrato da contenido a una clase de fuente que asume inmediata relevancia por sobre las demás, no sólo por la variedad e importancia de sus tipos nominados, más también por su amplia apertura hacia tipos innominados. La diferencia entre el delito y el cuasidelito se reduce a un punto puramente estructural, como es el diverso modo de ser del elemento subjetivo del ilícito, consistente en el dolo o en la culpa para que se trate, respectivamente, de un delito o de un cuasidelito. Funcionalmente, no hay diferencia entre ambos. Para los propósitos que constituyen nuestro actual interés, pues, podemos considerarlos unificadamente bajo el concepto de hecho ilícito 5 . Por otra parte, en materias civiles, la ley es muy

${ }^{5}$ En esta materia, mayor importancia cobra la distinción entre ilícitos de respon- 
excepcionalmente fuente de obligaciones. Aunque la figura del cuasicontrato tratada en el Código es abierta (artículo 2285: "hay tres principales cuasicontratos") ${ }^{6}$, de hecho también sus tipos específicos son escasos; y los que tradicionalmente se miran como tales suelen ser correlatos de ciertos contratos, de los que se diferencian tan sólo por carecer de su estructura convencional. El pago de fungibles no debidos es correlato del mutuo ${ }^{7}$; la agencia oficiosa lo es del mandato; y la comunidad incidental de la sociedad, con la que adicionalmente se diferencia por el dato estructural de la personalidad jurídica, propia de ésta y ausente en aquélla ${ }^{8}$.

sabilidad subjetiva (delitos, con dolo y cuasidelitos, con culpa) y de responsabilidad objetiva (sin culpa ni dolo), que determina algunas diferencias importantes de régimen. De esta manera, como en tantos otros casos, pareciere que va a recuperarse el sentido original de la distinción entre delitos y cuasidelitos, impreso por su creador, el profesor Gayo (mediados del siglo II a.C.), en orden a que los delitos exigen dolo o culpa, y que los cuasidelitos se cometen sin ninguna de ambas (Dig. 44,7,5-6). Justiniano mantuvo los conceptos (Inst. Iust. 4,5). Desaparecida la categoría de los ilícitos de responsabilidad objetiva, o sea, la de los cuasidelitos de Gayo y Justiniano, para mantener la distinción se distribuyó los ilícitos en dolosos (delitos) y culposos (cuasidelitos); y así llegó al Código Civil. La moderna reaparición de los ilícitos sin culpa ni dolo ha puesto en crisis esta clasificación.

${ }^{6}$ Quiero decir: cada vez que se verifique haber una obligación no nacida de la ley, mas de un hecho lícito no convencional, se está en presencia de un cuasicontrato. Así, por ejemplo, reviste este carácter el "droit de suite" establecido en el artículo 36 de la Ley No 17.336, sobre propiedad intelectual, merced al cual el autor chileno de pinturas, esculturas, dibujos o bocetos puede percibir el 5\% del mayor valor real que el que se lo adquirió obtenga al vender después la obra: véase, GuZMán Brito, A., Las cosas incorporales, cit. (n. 1), p. 89. Para otros casos, aunque discutidos de cuasicontratos, véase: Abeliuk Manasevich, René, Las obligaciones ( $3^{\text {a }}$ edición, Santiago, Editorial Jurídica de Chile, 1993), I, números 181-188, pp. 152-155.

${ }^{7} \mathrm{El}$ pago de infungibles no debidos es correlato de una figura desaparecida de los códigos modernos, mas no por ello inexistente en el tráfico jurídico, que los romanos denominaban dare ob rem, consistente en dar una cosa a otro, en espera convenida de seguir cierto fin lícito, de modo que el accipiens la debe restituir, a menos que sobrevenga el fin, caso en el cual la puede retener. Como el que paga da con el fin de extinguir una obligación, y tal fin no puede seguir, si la obligación por extinguir no existió, entonces el supuesto acreedor debe restituir lo que recibió y no puede retenerlo. Sobre el dare ob rem romano, véase una exposición general en GuZMÁn BRITO, Alejandro, Derecho privado romano (1 $1^{a}$ edición, $3^{\text {a }}$ reimpresión, Santiago, Editorial Jurídica de Chile, 2004), I, $\$ 136$, pp. 744 ss. Para detalles: Guzmán Brito, Alejandro, "Dare ob rem", en Caminos romanos. Viae Romanae. Estudios en homenaje a Francisco Samper Polo (Santiago de Chile, Universidad Andrés Bello, 2006), pp. 149-192.

${ }^{8}$ La categoría del cuasicontrato tuvo su precedente en Gayo, quien, en una obra suya, que se nos ha transmitido fragmentariamente a través de los Digesta Iustinia$n i$ (Dig. 44,7,1; 44,7,4; 44,7,5), distribuyó las obligaciones según su fuente (causa 
En tales circunstancias, pues, la relevancia del contrato como fuente de obligaciones no necesita ser exagerada.

2. Por causa de muerte, el paralelo funcional -no estructural, por cierto- del contrato es el legado de efectos obligacionales, cuya virtualidad en este sentido es amplísima, pues por medio de un legado así es posible establecer toda clase de obligaciones (véase el capítulo VII), tantas cuantas son posibles de establecer por medio de un contrato.

A esta materia nos hemos referido en otro lugar ${ }^{9}$. Ahora sólo basta presentar el esquema general.

Por legado de efectos obligacionales entendemos aquella disposición testamentaria por la cual el testador crea "una obligación nueva de dar, hacer o no hacer, a cargo de uno, varios o todos los herederos instituidos por el testador (o de un legatario) y, correlativamente, un crédito en favor del legatario contra el o los asignatarios gravados, frente a los cuales dispone

obligationis) en obligaciones nacidas de contratos, delitos y "figuras varias de causas" (variae causarum figurae). Este último miembro quedó constituido por obligaciones nacidas de fuentes no convencionales que nacen "como de un contrato" (quasi ex contractu) y que nacen "como de un delito" (quasi ex delicto), queriendo decir: obligaciones cuya fuente se aproxima o se parece a algún contrato y obligaciones cuya fuente se aproxima o se parece a algún delito, sin ser, empero, contrato ni delito, por faltarles cierto elemento estructural de uno u otro. En las fuentes que se aproximan a un contrato, sin serlo, el elemento estructural faltante es la convención: así en las obligaciones recíprocas nacidas de la gestión de los negocios de un ausente por el gestor y de los del pupilo por el tutor, en la obligación de pagar los legados por el heredero al legatario y en la de restituir lo recibido en pago indebido, respectivamente en correlación con las obligaciones contractuales derivadas de mandato, en los dos primeros casos, de estipulación, en el tercero y de mutuo o de datio ob rem en el cuarto. En las obligaciones de fuentes que se aproximan a un delito, sin serlo, el elemento estructural faltante es la culpabilidad (culpa o dolo): así en la obligación del juez en orden a responder por el ilícito de litem suam facere, o por el daño que causan las cosas que caen o se derraman desde lo alto, o de los empresarios de transporte marítimo, los posaderos y los administradores de establos por las cosas introducidas en el barco o en sus locales si fueron hurtada o dañadas, también en correlación con los delitos de damnum o furtum. Justiniano (Inst. 3,13,2) convirtió la tripartición gayana en una cuatripartición, al dividir el miembro de las variae causarum figurae en dos: obligaciones "que nacen como de un contrato" y "que nacen como de un delito". Pero mantuvo los conceptos gayanos, aunque, entre las obligaciones nacidas quasi ex contractu, ańadió la comunidad (incidental) cuyo correlato es la societas. Sobre todo esto, véase: GuZMán Brito, Alejandro, Derecho privado romano, cit. (n. 7), II, $\$ 132$, pp. 701-708.

${ }^{9}$ Véase: Guzmán Brito, Alejandro, La tipología de los legados en el Derecho civil chileno, en Revista de Derecho de la Pontificia Universidad Católica de Valparaíso 27 (Valparaíso, 2006, Semestre I), cap. III, pp. 62-71. 
de una acción personal de cumplimiento, llamada acción del testamento (actio ex testamento)" ${ }^{10}$. Las formas generales de este legado son:

i) El legado obligacional de una cosa corporal no fungible, o sea, de una especie o cuerpo cierto, perteneciente al testador, del tipo: "Que mi heredero quede obligado a dar mi fundo Corneliano a Ticio"; o bien: "Que mi heredero dé mi fundo Corneliano a Ticio"; o asimismo: "Ordeno a mi heredero dar mi fundo Corneliano a Ticio".

ii) El legado de una cosa corporal no fungible, vale decir, de una especie que pertenece al asignatario a quien se impuso la obligación de darla (artículo 1107 CC.). El testador dispone: "Que mi heredero quede obligado a dar su fundo Corneliano a Ticio"; o también: "Que mi heredero dé su fundo Corneliano a Ticio"; o incluso: "Ordeno a mi heredero dar su fundo Corneliano a Ticio".

iii) El legado obligacional de un derecho real preconstituido, principal y transmisible, perteneciente al testador, del tipo: "Que mi heredero dé a Ticio la concesión minera de explotación tal, que me pertenece”.

iv) El legado obligacional de constitución de un nuevo derecho real a favor del legatario, sobre cosa del testador, como si se dispone: "Que mi heredero quede obligado a dar (o sea, a constituir) un usufructo sobre el fundo Corneliano [que quedará en la herencia]”.

v) El legado obligacional de un crédito perteneciente en vida al testador (o a un asignatario), para que el heredero gravado con el legado lo ceda al legatario, del tipo: "Que mi heredero quede obligado a ceder a Cayo tal crédito que tengo contra Ticio"

vi) El simple legado de especies indeterminadas de cierto género, como si se dispone: "Que mi heredero quede obligado a dar 1.000 a Ticio"; o: "Lego 1.000 a Ticio", que es el habitualmente denominado "legado de géneros".

Pertenecen también a esta clase ciertos legados especiales, que no reexpondremos aquí, porque con lo dicho es suficiente para hacer ver la amplitud de posibilidades obligacionales que ofrece esta forma de asignar ${ }^{11}$.

En cualquier caso, queda constituido el cuasidominio de un derecho personal conferido por el legado a favor del legatario contra el gravado con el legado, que se constituye en su deudor, y sujeto, por ende, a la acción personal, que denominamos actio ex testamento, para que haga la tradición, constitución o cesión al legatario, según los casos, igual que si se hubiese obligado a hacerla por contrato.

Hasta el momento hemos conducido el examen con base en obligacio-

${ }^{10}$ Ibíd., p. 62.

${ }^{11}$ Ibíd., pp. 68-71. 
nes de dar; pero se lo podría extender a las obligaciones de hacer o no hacer, que asimismo admiten ser creadas por un legado. Si el testador dice: "Que $\mathrm{mi}$ heredero Ticio, que es orfebre, confeccione una estatua para Cayo, con el bronce que éste le entregará y de acuerdo con las especificaciones que le señale", entonces el heredero queda obligado a hacer, esto es, a la confección de la obra material indicada, igual que si se hubiese obligado merced a un arrendamiento. Y si el testador dice: "Que mi heredero Ticio no revoque antes de cinco años el permiso que le tengo dado a Cayo de poder transitar por mi fundo Corneliano", ahora el heredero resulta obligado a no hacer, igual que si se hubiera obligado a ello por contrato.

Así, pues, el contrato y el legado de efectos obligacionales quedan situados como maneras normales y generales de crear voluntariamente obligaciones de cualquier clase, entre vivos el primero, y por causa de muerte el segundo.

3. Dentro del mismo ámbito a que aquí nos referimos, conviene mencionar especialmente el paralelismo que se genera entre vivos y por causa de muerte en tema de alimentos voluntarios, que normalmente asumen la forma obligacional, sin que quede excluida, empero, la forma real.

El establecimiento de alimentos voluntarios, vale decir, de aquellos que se dan a favor de cierta persona, sin haber previa obligación legal de darlos, puede ser instituido entre vivos merced a una convención entre alimentante y alimentario, que normalmente tiene por causa a una donación. Por lo general asume forma obligacional: el alimentante se obliga a dar una única vez una cosa o un derecho bajo el concepto de alimentos; o bien se obliga a dar pensiones periódicas de dinero (o, aunque raramente, de otros fungibles) bajo el mismo concepto. Por cierto, como quedó adelantado, la dación voluntaria de alimentos puede revestir forma real, como si alguien, en vez de obligarse, transfiere una única vez cierta cosa o un derecho, a título de tales.

A semejante establecimiento en todas sus formas se refiere el artículo 337 CC.; pero también el artículo 1402 CC., si lo donado es el derecho de percibir una cantidad periódicamente, que con frecuencia asume la prestación de alimentos, y que entonces exige insinuación en determinadas condiciones. Que, por lo demás, también es exigida aunque la donación asuma la forma real u obligacional de dar cosas o derechos cuyo valor exceda dos centavos, porque igualmente rige el artículo 1401 CC. la operación.

Sin embargo, también se pueden asignar alimentos voluntarios "en testamento" dice el mismo artículo 337 CC.; y esta forma de decir no significa otra cosas que un legado de alimentos voluntarios; que puede asumir cualesquiera de sus formas, vale decir, real, obligacional o liberatoria. A tales se refieren los artículos 1171 inciso $1^{\circ}$ y 1361 CC. 


\section{CIRCULACIÓN VOLUNTARIA DEL DOMINIO DE LAS COSAS CORPORALES ENTRE VIVOS MEDIANTE TRADICIÓN Y POR CAUSA DE MUERTE MERCED A LEGADOS}

\section{Concepto de la circulación de cosas.}

En sentido amplio, hay "circulación" del dominio de las cosas corporales (o simplemente "circulación de las cosas corporales) cuando éstas ingresan al patrimonio de una persona desde el patrimonio de otra e, incluso, desde un "no-patrimonio", como es el caso de las res nullius ocupadas. En este caso, el factor que da su dinamismo a la circulación es cualquier modo de adquirir. Una noción así de general presenta escasa utilidad, entre otras razones, porque el efecto, esto es, la circulación, tiende a confundirse con su causa, es decir, con los modos de adquirir. Mayor utilidad presenta la de "circulación" en sentido estricto. Por tal entendemos el traslado del dominio de las cosas corporales debido a un acto voluntario del actual dueño, que es, por ende, el factor que da dinamismo a la circulación. Entre vivos, tal acto es la tradición. Por causa de muerte, el legado de efecto dominical. Del concepto, por consiguiente, quedan excluidas la ocupación, la accesión y la prescripción adquisitiva, porque en su configuración total no interviene un acto jurídico del anterior dueño, si lo hubo, y porque sólo hacen nacer un dominio nuevo sobre las cosas de que se trate. También queda excluida la especie de sucesión por causa de muerte denominada herencia, que en sí misma tampoco depende de un acto jurídico del anterior dueño, incluso si es testamentaria, porque el testamento, cuando designa herederos, sólo regula el destinatario y la cuantía de la adquisición sucesoria (amén de otros extremos accidentales), que de todos modos se producirá sin testamento y aún contra el testamento. Por lo demás, dogmáticamente la función de la herencia, sea intestada, sea testada, consiste en la sustitución patrimonial universal de la persona del difunto por la del heredero, que sólo por consecuencia hace adquirir a éste el dominio de las cosas que pertenecían a aquél.

Lo que se ha dicho para la circulación de las cosas corporales vale igualmente para la de las incorporales. Supuesta la preexistencia de derechos reales o personales, que alguna vez fueron constituidos en cabeza de alguien, el cuasidominio de tales derechos puede empezar a circular hacia terceros mediante un acto voluntario del anterior cuasidueńo; lo que acaece merced a su cesión (tradición), entre vivos y a un legado de efectos reales, por causa de muerte.

Así, pues, cabe ahora examinar las funciones circulatorias de la tradición y del legado de cosas corporales. 


\section{Circulación de cosas corporales entre vivos mediante tradición.}

Entre vivos, las cosas corporales, o sea, su dominio, circulan, en sentido restringido, merced a la tradición. No dedicaremos un discurso mayor al tema, que es suficientemente conocido; y nos limitaremos a recordar que la tradición aparece definida en el artículo 670 inciso $1^{\circ} \mathrm{CC}$. como una "entrega"; y que, bajo este respecto, el concepto queda reducida a las cosas corporales muebles, porque el artículo 686 inciso $1^{\circ} \mathrm{CC}$. establece que la tradición del dominio de los bienes raíces, con lo cual se refiere a las cosas corporales inmuebles, consiste en una "inscripción" del título de la transferencia. Aunque las estructuras de la tradición de muebles y de la de inmuebles son radicalmente diferentes, en la misma medida en que son diferentes las estructuras de los actos reales, como es la entrega material de un mueble, y de los actos solemnes, como es la inscripción de un documento (el título de transferencia) en otro documento (el Registro de Propiedad), el Código, adoptando un punto de vista funcional, equipara ambas bajo el concepto único de tradición, en vez de separarlas como estructuras distintas, cada cual con su nombre, aunque con la misma función adquisitiva; no sin consecuencias dogmáticas y prácticas graves, de que no trataremos ahora.

En cualquier caso, pues, que el dominio de una cosa corporal deba ser transferido voluntariamente entre vivos por su actual dueño a uno que va a adquirirlo, se necesita una tradición, fundada en algún título concreto y típico de transferencia (artículo 675 CC.), como compraventa, permuta, donación irrevocable (en sus diferentes especies), pago, dación en pago, crédito (como en el mutuo), aporte en sociedad, o transacción; cumplida por entrega, si se trata de la transferencia de un mueble; o por inscripción, cuando de inmuebles es el caso. La consecuencia del acto es dar el dominio y la posesión de la cosa al adquirente; o sólo la posesión, si intervino algún vicio, sea en el título, sea en la tradición, que permite la operación subsidiaria y sanadora, de la prescripción adquisitiva (artículo 2492 y demás pertinentes del título $42^{\circ}$ del libro IV CC.).

\section{Circulación de cosas corporales por causa de muerte mediante legado de} efectos reales dominicales.

Las cosas corporales, o sea, el dominio de ellas, puede también circular por causa de muerte merced a la intervención de un legado de efectos reales dominicales. Consiste él en la asignación en dominio a un legatario, de una cosa corporal no fungible determinada, que el Código denomina especie o cuerpo cierto, siempre que pertenezca al testador ${ }^{12}$, del tipo: "Lego y hago

\footnotetext{
${ }^{12}$ Artículo 1107 CC.: "El legado de especie que no es del testador [...] es nulo"; así
} 
propietario de mi fundo Corneliano a Ticio"; o: "Doy y lego mi fundo Corneliano a Ticio", y cada vez que el testador use palabras (no sacramentales, desde luego) de sentido real que correspondan a una voluntad en el mismo sentido, como las indicadas. La asignación hace dueño ${ }^{13}$. ipso iure al legatario retroactivamente desde la delación, supuesta su aceptación (artículo 1239 inciso $2^{\circ} \mathrm{CC}$.), y le da la acción reivindicatoria contra el actual poseedor de la especie (artículo 889 CC.), aparte de una personal contra el asignatario gravado para obtener su mera entrega material, igual que si el interesado la hubiera adquirido entre vivos por tradición.

\section{CIRCULACIÓN VOLUNTARIA DEL CUASIDOMINIO DE DERECHOS REALES COMO ESPECIES DE COSAS INCORPORALES ENTRE VIVOS MEDIANTE CESIÓN (TRADICIÓN) Y POR CAUSA DE MUERTE MERCED A LEGADOS}

En el capítulo anterior examinamos la circulación de cosas corporales entre vivos y por causa de muerte que impulsan respectivamente la tradición y el legado de efectos reales dominicales. Cumple ahora estudiar una circulación semejante que también impelen la tradición y el legado, pero con respecto al cuasidominio de las cosas incorporales. Distribuiremos el tema en este capítulo, reservado a la circulación del cuasidominio de las especies de cosas incorporales que son los derechos reales; $y$ en el que sigue inmediatamente, destinado a lo propio concerniente a las otra especies de aquéllas, que son los derechos personales o créditos.

1. Entre vivos, una vez constituidos los derechos reales, éstos pueden empezar a circular por tradición, que solemos, y también la ley, llamar "cesión"; y los ya transferidos una vez, pueden continuar haciéndolo indefinidamente en el futuro, hasta que se extingan.

a) La regla general se presenta en los artículos 670 inciso $2^{\circ}$ y 686 inciso $2^{\circ} \mathrm{CC}$., que ya antes hemos presentado. Esta regla general aparece individualizada en algunos casos para derechos reales determinados. Así en el Código Civil, sus artículos 793 inciso $1^{\circ}$ y 1909 ss. admiten, respectivamente, la cesión del usufructo y del derecho de herencia; los artículos 2 inciso $1^{\text {a }}$ y 92 CM., la de los derechos reales de concesión de exploración

que el legado real de especie exige que ésta pertenezca al testador, a menos que, habiendo sido ajena al momento de testar, haya pasado a su dominio antes de morir, pues entonces se valida (artículo 1108 CC.).

${ }^{13}$ Como la sucesión por causa de muerte es un modo de adquirir (artículo 588 CC.), y el legado es un tipo de tal sucesión (a título singular: artículo 951 inciso $1^{\circ}$ CC.), se deduce que, cuando lo legado es una especie, el legatario, porque sucede al testador en esa especie (artículo 951 inciso $3^{\circ}$ CC.), precisamente adquiere su dominio. 
y explotación, y de pedimento y manifestación; el artículo 21 CA., la de los derechos de aprovechamiento; y los artículos 17 de la Ley No 17.336 y 14 de la Ley No 19.039, la de los derechos de autor (patrimonial) y de patente industrial, respectivamente.

b) Pero la regla general de la transferibilidad de los derechos reales ofrece la excepción de los derechos reales de uso y habitación, que "no pueden cederse a ningún título", como dispone el artículo 819 inciso $1^{\circ} \mathrm{CC}$. El derecho real de autor (moral) tampoco puede ser objeto de tradición, porque el artículo 16 de la Ley No 17.366 lo declara inalienable.

c) Dicha regla, además, sufre modificaciones en cuanto el traspaso de algunos derechos reales tiene un modo de operar especial.

i) Tal acaece con los derechos reales de servidumbre. Uno de los principios generales que los rigen es el de su inseparabilidad con respecto al dominio sobre el predio dominante al que se ligan activamente, o el predio sirviente al que adhieren pasivamente (artículo 825 CC.) ${ }^{14}$. Otro es el de su accesoriedad activa o pasiva a cada dominio, de donde que la inseparabilidad ceda en beneficio del dominio y no de la servidumbre: es ésta la que sigue a aquél y no a la inversa. De ambos principios se sigue que: i) transferido el dominio del predio dominante o el del sirviente, queda coetáneamente transferida la servidumbre activa o pasiva; y ello por efecto legal, vale decir, sin necesidad de expresarlo; ii) no se pueden transferir los respectivos dominios, sin transferir las respectivas servidumbres, a menos que contemporáneamente se las extinga; iii) no se pueden transferir las servidumbres sin transferir el dominio de los predios en que inciden activa o pasivamente, para trasladarlas a otros predios; iv) no se pueden transferir los dominios del predio dominante o del sirviente a uno y las pertinentes servidumbres activa o pasiva a otro, para que sean correspondientemente aplicadas a predios diversos o queden en suspenso hasta que se determine a qué predios aplicarlas ${ }^{15}$.

${ }^{14}$ Cuando el artículo 825 CC. dice ser inseparables “del predio" las servidumbres, la inseparabilidad que predica es con respecto, no al predio, en cuanto cosa, sin embargo, mas con respecto al dominio de éste. De hecho todo derecho real, incluso el dominio, y también todo derecho personal, es inseparable de la cosa en que incide, precisamente porque es su objeto, así que la separación de ambos implicaría dejar sin objeto al derecho. Se ve claro el punto, por ejemplo, en el usufructo: inseparable de la cosa en que recae, es separable del dominio, que queda siempre radicado en el nudo propietario; así que la nuda propiedad y el usufructo circulan separadamente entre vivos. Las servidumbres, que por supuesto y no merced a lo declarado por el artículo 825 CC., son inseparables del predio en que recaen, son, además, inseparables del dominio sobre cada predio y no pueden circular separadamente de éste.

${ }^{15}$ Debemos interpretar que el artículo 825 CC. contiene una norma prohibitiva, precisamente la de separar las servidumbres del predio a que activa o pasivamente 
Como se puede apreciar, la imposibilidad de ceder servidumbres separadamente del dominio de la cosa en que inciden no deriva de alguna inidoneidad de la cesión para producir tal efecto, sino de la inseparabilidad del dominio sobre el predio y de la titularidad de sus servidumbres y de la accesoriedad de éstas. Proviene, pues, de un rasgo de la servidumbre, no de la cesión.

ii) Algo semejante tiene lugar en los derechos reales de prenda e hipoteca. En el caso, menester es distinguir una triple inseparabilidad y accesoriedad: con respecto al dominio de la cosa, al crédito y a la deuda.

Aunque no esté dicho directamente, como lo está para las servidumbres, los derechos reales de prenda e hipoteca también están regidos por un principio de inseparabilidad entre cada uno de ellos y el dominio de la cosa que gravan; y asimismo por uno de accesoriedad de tales derechos al mencionado dominio, porque aquéllos lo siguen, pero no a la inversa. De ambos nuevamente se puede colegir que no pueden circular separadamente. Por consiguiente: i) transferido el dominio de la cosa gravada con prenda o hipoteca, aquél pasa coetáneamente con esos gravámenes al adquirente, aunque nada expreso se diga (artículos 2393 y 2404 CC.). Pero no es que la transferencia de la cosa gravada tenga también como objeto a la prenda o a la hipoteca: el que pudo transferir dicha cosa, por ser su dueño, no pudo transferir aquéllos derechos, en efecto, porque no es su titular. El fenómeno, pues, se debe nada más que al carácter real de la prenda o la hipoteca, que por definición implica que ellos sigan al dominio de la cosa; ii) no se puede transferir el dominio de la cosa gravada sin la prenda o la hipoteca que la grava, a menos que contemporáneamente se las extinga; iii) no se pueden transferir la prenda ni la hipoteca sin transferir el dominio de la cosa en que inciden, para retenerlas y trasladarlas a otra cosa; iv) no se puede transferir el dominio de la cosa gravada a uno y la prenda o la hipoteca a otro, para que sean correspondientemente aplicadas a cosas diversas o queden en suspenso hasta que se determine a qué cosas aplicarlas.

En segundo lugar, la prenda y la hipoteca son inseparables del crédito que garantizan y accesorios suyos, al que siguen. Por consiguiente: i) cedido el crédito que gozaba de la garantía de una prenda o hipoteca, éstas pasan coetáneamente con el crédito al cesionario (artículo 1906 CC.), aunque nada expreso se diga; ii) no se puede ceder el crédito sin la prenda o la hipoteca que lo garantizan, a menos que contemporáneamente se las extinga; iii) no se pueden transferir la prenda ni la hipoteca sin ceder el

pertenecen. En consecuencia, cualquier acto o contrato que contenga una separación adolece de objeto ilícito en los términos de la parte fine al del artículo 1466 CC., en donde la palabra "contrato" va interpretada como "acto jurídico". 
crédito que garantizan, para trasladarlas a otro crédito; iv) no se puede ceder el crédito a uno y la prenda o la hipoteca a otro, para que sean correspondientemente aplicadas a un crédito diverso o queden en suspenso hasta que se determine a qué crédito aplicarlas.

Lo dicho sobre la relación de inseparabilidad y accesoriedad entre el crédito y la prenda y la hipoteca vale, mutatis mutandis, para una inseparabilidad y accesoriedad que rigen entre la deuda y ambas garantías: tampoco ésta pueden circular separadamente de aquéllas.

En consecuencia, los derechos reales de prenda e hipoteca pueden circular entre vivos; pero de una manera especial: con el dominio de la cosa gravada, con el crédito garantizado o con la deuda por la cual se las otorgó.

iii) El derecho real de censo es inseparable tanto del derecho personal de censo como del dominio de la finca acensuada; así que no puede ser cedido separadamente con respecto a uno u otro (artículo 2033 CC.).

2. La circulación de derechos reales, que entre vivos tiene lugar mediante cesión, por causa de muerte tiene paralelamente lugar merced a un legado de efecto real.

a) Los derechos reales que estaban en cabeza del testador pueden, pues, pasar a terceros mediante aquél acto, una vez muerto aquél. La amplia dicción del artículo 1127 CC., que cubre la hipótesis de constitución de derecho reales nuevos por legados, también cubre la presente, de transmisión de derechos reales preexistentes; pues dice: "Pueden legarse [...] los derechos y acciones", es decir, las cosas incorporales (artículos 565 inciso $3^{\circ}$ y 577 inciso $2^{\circ}$ última parte); y una de sus especies está constituida por los derechos reales (artículo 576 CC.). También el caso está a veces especialmente previsto en las leyes. Así para el derecho real de censo (artículo 2043 CC.: en donde "por testamento" significa especialmente "por legado"), los derechos de pedimento, manifestación, exploración y explotación (artículo $2 \mathrm{CM}$.), el derecho de aprovechamiento de aguas (artículo 21 CA.), el derecho moral de autoría, pero sólo al cónyuge sobreviviente o a las personas que tienen título legal para haber sucedido abintestato al autor (artículo $15 \mathrm{~L}$. N $\mathrm{N}^{\circ} 17.336$ ), y el derecho de patente "industrial" (artículo 14 L. N ${ }^{\circ} 19.030$ ).

El legado a que nos referimos es aquel que atribuye inmediatamente al legatario la titularidad o cuasidominio de un preconstituido derecho real transmisible suyo, que por ende, ya se encontraba en su patrimonio desde algún momento de su vida, de manera de pasar ahora al legatario. Su titular, pues, los puede legar con efecto real, mediante formulaciones del tipo: "Doy y lego el derecho de explotación de la mina tal a Ticio". Cuando el legatario acepte su asignación, empieza a disponer de la acción 
reivindicatoria de derechos reales (artículo 891 inciso $1^{\circ} \mathrm{CC}$.) contra todo aquél que niegue la existencia de su derecho, poseyendo la cosa sobre que éste recae o ejerciendo de hecho el derecho ajeno.

Pero esta regla general también sufre excepciones y modificaciones.

b) En primer lugar las excepciones.

i) Comparece de inmediato el derecho real de usufructo que, si bien transferible entre vivos por tradición (artículo 793 CC.), cuando pertenece a una persona natural no es transmisible por legado (ni por herencia), como lo dispone directamente el artículo 773 inciso $2^{\circ} \mathrm{CC}$. La razón deriva del carácter vitalicio de este derecho: él puede durar toda la vida del usufructuario, su titular; pero no más tiempo que el de su vida (artículo 770 incisos $1^{\circ}$ y $2^{\circ}$ CC.). Por consiguiente, muerto el usufructuario, se extingue el derecho (artículo 806 inciso $2^{\circ}$ CC.); así que un legado de efecto real que recaiga sobre él es nulo por falta de objeto.

Si el usufructo pertenece a una corporación o fundación, que también es transferible entre vivos, caduca al cabo de los treinta ańos contados desde su constitución (artículo 770 inciso $3^{\circ} \mathrm{CC}$.), aunque, por consiguiente, ínterin haya sido transferido. Pero entretanto, como las personas jurídicas no pueden legar, debido a que no pueden testar ${ }^{16}$, no lo pueden transmitir. Con todo, si se diere el caso de su disolución, debe tener lugar el traspaso de sus bienes en la forma prevista por el artículo 561 CC.; y si entre tales bienes se encontrare un usufructo, él sufre la suerte señalada por esa disposición.

Como se ve, que el usufructo no pueda ser objeto de un legado traslativo del derecho es consecuencia, no de cierta inidoneidad de la figura del legado mismo para producir la traslación, sino del derecho para ser trasladado por causa de muerte.

ii) El mismo régimen y sus razones fundantes se aplican a los derechos reales de uso y habitación. Puesto que ambos se extinguen de la misma manera que el usufructo (artículo 812 CC.: "pierden"), eso significa que también se extinguen por la muerte del usuario o del habitador; de donde que no puedan ser legados ni hacer parte de sus respectivas herencias. Esto último lo dice expresamente el artículo 819 inciso $1^{\circ}$ CC.: "son intransmisibles a los herederos"; la cual norma omite añadir: "y a los legatarios". Pero la intransmisibilidad del uso y la habitación a estos deriva indiscutiblemente de su carácter vitalicio, no dicho expresamente para ellos, a su

\footnotetext{
${ }^{16}$ No está dicho expresamente; pero esta imposibilidad es sistemática. El testamento y la sucesión, en general, suponen la muerte de una persona; y la muerte a que el Derecho sucesorio se refiere es la natural (artículo 78 CC.) de las personas naturales. Las personas jurídicas no mueren. Decir que "mueren" cuando se extinguen o disuelven es sólo un lenguaje metafórico.
} 
vez, pero afirmado implícitamente por el artículo 812 CC., que fulmina su pérdida por causas iguales a las del usufructo, entre las cuales el artículo 806 inciso $2^{\circ} \mathrm{CC}$. coloca a la muerte del usufructuario, lo que en tema de uso y habitación, se convierte en "muerte del usuario o habitador".

iii) Acerca de si el derecho real de herencia puede ser legado por su actual titular, nos remitimos al lugar en que antes hemos discutido el punto, dándole una respuesta positiva ${ }^{17}$.

c) También se presentan ciertas modificaciones que afectan a algunos derechos reales en su transmisibilidad por legado.

En general, lo que ahora deberíamos decir ya fue dicho antes a propósito de la cesión de servidumbres entre vivos, que vale para su transmisión por legado. Esto, pues, significa que las servidumbres preexistentes no se pueden legar separadamente con respecto a los fundos dominante o sirviente; y legados uno u otro se legan contemporáneamente sus servidumbres activas o pasivas, como lo expresa el 1125 CC. que expresa: "La especie legada pasa al legatario con sus servidumbres [...]".

ii) Algo semejante acaece con los derechos reales de prenda e hipoteca, que no pueden ser legados separadamente en relación con la cosa gravada por ellas, el crédito o la deuda garantizados. Por consiguiente, legado el dominio de la cosa gravada con prenda o hipoteca por su dueño, vale decir, por el que constituyó una u otra, aquél pasa con esos gravámenes al legatario: es lo que reconoce el artículo 1225 CC.: "La especie legada pasa al legatario sus [...] demás cargas reales".

A la inversa, el titular de los derechos de prenda o hipoteca no podría legarlos, porque ello necesariamente implicaría separarlos del dominio, que no tiene y que no puede, por ende, legar. El Código, con todo, trata este caso muy especial de legado de prenda en su artículo 1128: "Si la cosa que fue empeñada al testador, se lega al deudor, no se extingue por eso la deuda, sino el derecho de prenda [...]". El caso consiste en que un acreedor, al que había sido entregada una especie mueble por su deudor o un tercero, para garantizarle la deuda, en su testamento lega esa especie al deudor. Pero debemos distinguir dos situaciones: que el deudor-legatario era el pignorante y, por ende, dueño de la especie empeñada; o que no lo era y pignorante había sido un tercero, que dio prenda por el deudor. En ambos casos, empero, sigue en pie que el acreedor-testador no pudo legar válidamente la especie, no sólo al deudor, mas a nadie, por no ser el dueño de ella; así que, en rigor, ese legado es nulo (artículo 1107 primera parte CC. $\left.{ }^{18}\right)$. Aunque lo anterior es suficiente, en el caso de haber sido

\footnotetext{
${ }^{17}$ Véase: Guzmán Brito, A., La tipología de los legados, cit. (n. 9), pp. 59-60.

${ }^{18}$ Dejemos a un lado los casos en que el legado de cosa ajena vale.
} 
pignorante el deudor, de modo que el legado de marras fue de cosa propia del legatario, se agrega que un tal legado tampoco vale. Pero el Código, en vez de seguir la regla de la nulidad del legado, le atribuye el efecto de extinguir la prenda.

Puestos en el evento de que el legatario era el pignorante, no podemos dejar de interpretar que lo acaecido entonces es quedar construido un legado que tiene por objeto el derecho real de prenda, que se extingue por confusión, porque el dueño del mueble empieza a ser titular del derecho real de prenda sobre una cosa propia, lo que es imposible. En otras palabras, el Código convierte el legado nulo de cosa ajena pignorada en legado válido del derecho real de prenda, y presenta él mismo la conclusión de tal conversión, que es la extinción del derecho legado.

En el caso en que el pignorante hubiera sido un tercero distinto al deudor, el legado de la cosa pignorada a este último todavía podemos construirlo como un legado del derecho de prenda al mismo; y entonces acaece que el deudor empieza a tener un derecho real de prenda en cosa ajena, más para garantizar una deuda suya contra sí mismo, lo que no es posible.

iii) El derecho real de censo, como es inseparable del derecho personal de censo y del dominio de la finca acensuada, no puede ser legado separadamente con respecto a uno u otro (artículo 2033 CC.).

Por consiguiente, los derechos reales preexistentes pueden circular mediante legado de efectos reales en los mismos casos y bajo las mismas modalidades en que pueden circular entre vivos por cesión o tradición, si cumplen con el requisito adicional de ser transmisibles.

\section{CIRCULACIÓN DEL CUASIDOMINIO DE DERECHOS PERSONALES COMO ESPECIES DE LAS COSAS INCORPORALES ENTRE VIVOS MEDIANTE CESIÓN (TRADICIÓN) Y POR CAUSA DE MUERTE MERCED A LEGADOS}

1. Entre vivos, los derechos personales circulan de cabeza en cabeza a través de la tradición, que en la especie toma el nombre de "cesión de créditos". Su régimen está fijado en el artículo 699 CC., en el $\$ 1$ del título $25^{\circ}$ del libro IV CC. y en el título $4^{a}$ del libro II C. de C. ${ }^{19}$. La cesión se ejecuta según que el crédito sea nominativo, a la orden o al portador.

2. Por causa de muerte, los créditos circulan mediante el legado de crédito de efectos reales, en la misma función con que entre vivos lo hacen por cesión.

${ }^{19}$ Véanse también los artículos 6, 7 y 8 de la Ley No 19.983 (DO. 12 nov. 2004), sobre la cesión de créditos que constan en facturas. 
a) El enunciado del artículo 1127 CC.: "Pueden legarse [...] los derechos y acciones", que antes invocamos para el legado de derechos reales preexistentes, puede ser traída ahora para fundar el legado de créditos preexistentes, o sea, de derechos personales que tenía en vida el testador, sin duda comprendidos en la expresión "derechos" (artículos 565 inciso $3^{\circ}, 576$ y 578 CC.).

Al decir legado de crédito "de efectos reales" nos referimos a un legado que traspase el crédito asignado directamente del testador al legatario, sin que, por ende, alcance a pertenecer a la herencia y sea un heredero (o todos o un legatario) los encargados de cederlo (entre vivos) al legatario, para cumplir el legado, pues en tal caso el legado sería de efectos obligacionales, al cual ya nos referimos ${ }^{20}$. Aquel de que hablamos, pues, tiene que estar concebido conforme con un esquema como éste: "Lego a Ticio el crédito que tengo contra Cayo".

b) El Código no ha regulado con detalle el legado de créditos. A él se refieren, con todo, los incisos $2^{\circ}$ y $3^{\circ}$ del artículo 1127 CC.

De acuerdo con el primero, el legado del título de un crédito debe hacer entender que lo legado es el crédito mismo, vale decir, que la disposición tiene por objeto la cosa corporal consistente en la materialidad del título, pero no sólo ella, sino también la cosa incorporal, o sea, el crédito que aquél porta; lo que es del todo natural. La inversa es también verdadera: legado un crédito, se entiende legado su título.

La segunda parte del inciso $3^{\circ}$ del artículo 1127 CC. dice que el legado de un crédito "no subsiste sino en la parte del crédito [...] que no hubiere recibido el testador". Literalmente esto significa que si el crédito fue pagado parcialmente al acreedor-testador, su legado de ese crédito recae únicamente sobre la parte no pagada, de guisa que el legatario no puede aspirar al todo. Ahora bien, por analogía debemos entender que el mismo régimen se aplica cuando entretanto el crédito legado hubo de extinguirse parcialmente por otra causa distinta al pago parcial. De esta manera, por ejemplo, si el testador había remitido o novado una parte del crédito legado, su asignación tan sólo ha de recaer sobre la parte subsistente o no remitida o novada.

Según la primera parte del inciso $3^{\circ}$ del artículo en examen, el legado de un crédito incluye el de sus intereses devengados. Por tales debemos entender a aquellos que el artículo 647 inciso $2^{\circ}$ CC. llama "pendientes", y define como intereses ya debidos pero aún no cobrados, porque estos últimos se denominan "percibidos". Así que el legado del crédito no incluye los intereses percibidos, que propiamente no son intereses, sino

${ }^{20}$ Véase, más arriba, el capítulo III, 2. 
dinero (eventual pero raramente otras cosas) que fue incorporado en el patrimonio del acreedor y que forma parte de la masa general de su herencia, si no fue gastado; y es lo que, en final de cuentas, dice la segunda parte del inciso $3^{\circ}$ del artículo 1127 CC., en orden a que el legado de un crédito "no subsiste sino en la parte [...] de los intereses que no hubiere recibido el testador", porque la expresión "recibir los intereses" significa, en fin de cuentas, "percibirlos" ${ }^{21}$. La ley no necesitó decir que el legado de crédito incluye también los intereses que son futuros respecto del momento en que se hace eficaz el legado, por los cuales se entienden los aun no devengados a ese momento, pero cuya devengación se espera, generalmente a medida del transcurso del tiempo. No necesitó decirlo porque, una vez hecho eficaz el legado, su nuevo titular, vale decir, el legatario, tiene derecho a ellos a medida que se devenguen, no ya por derecho de legado, sino por derecho de titularidad en el crédito o cuasidominio, que es, mutatis mutandis, lo que también dice el artículo 648 CC.

El legado de un crédito incluye las prendas e hipotecas y las fianzas y otras cauciones que lo garantizaban, lo mismo que los privilegios y las excepciones reales que lo favorecían: todos estos accesorios, pues, pasan al legatario. Pero no le llegan las excepciones personales del acreedor-testador. Se trata, así, de un efecto semejante al de la cesión entre vivos de un crédito (artículo 1906 CC.).

\section{RENUNCIA DE DERECHOS REALES ENTRE VIVOS Y POR CAUSA DE MUERTE}

1. Entre vivos, el acto abdicativo de un derecho real por su titular o cuasidueńo, vale decir, su renuncia de aquél, ya es posible de acuerdo con el general artículo 12 CC., que admite la renuncia de los derechos con tal que sólo miren al interés particular del renunciante y no esté prohibida su renuncia. Pero a veces ello está reiterado para derechos singulares, como para la renuncia del usufructo (artículo 806 inciso $6^{\circ} \mathrm{CC}$.), del uso y de la habitación (artículo 812 CC: "se pierden de la misma manera que el usufructo"), de las servidumbres (artículo 885 inciso 40), de la prenda (artículo 1654 inciso $2^{\circ}$, que la denomina "remisión"), de la hipoteca (artículo 2434 inciso $4^{\circ}$ y la llama "cancelación", cfr. con el artículo 1654 inciso $\left.2^{\circ}\right)^{22}$, de los derechos reales mineros (artículos 162 CM. y 18 inciso $3^{\circ}$ Ley

\footnotetext{
${ }^{21}$ También, por analogía, debe entenderse que si la obligación de pagar intereses se extinguió parcialmente debido a causa distinta a su pago, el legado del crédito no subsiste sobre los intereses extinguidos.

${ }^{22} \mathrm{La}$ renuncia a la prenda y a la hipoteca es posible sin remitir la deuda principal (artículo 1654 inciso $2^{\text {a }}$ CC.)
} 
orgánica constitucional sobre concesiones mineras), de los derechos reales de patente industrial (artículo 14 inciso $1^{\circ} \mathrm{L} . \mathrm{N}^{\circ} 19.039$ ) y del derecho de aprovechamiento de aguas (artículos 129 CA. y 12 CC.). El censo real (en forma separable del censo personal), porque nada particular dice la ley, es renunciable de acuerdo con el artículo $12 \mathrm{CC}$. Pero los derechos reales de autor (moral) y autoría (patrimonial) son irrenunciables (artículos 16 y 86 L. No 17336 ${ }^{23}$. Con respecto al derecho real de herencia cabe preguntarse si es renunciable. Su renuncia tendría que ser construida sobre la base de una herencia deferida y ya aceptada por el heredero y aún indivisa, quien con posterioridad la abdicara. Pero esto no parece posible, porque equivaldría a dejar sin efecto la aceptación, que es irrevocable (arg. ex artículo 1234 CC.). En sustitución, el heredero llamado a una herencia puede abstenerse de adquirirla mediante su repudiación (artículo 1225 CC.), aunque ello no es una renuncia, porque ésta supone una abdicación de lo que se tiene, no una omisión de adquirir lo que no se tiene.

2. La abdicación o renuncia de derechos reales pronunciada entre vivos tiene su paralelo por causa de muerte en una disposición testamentaria abdicativa de tales derechos ${ }^{24}$, que constituye propiamente un legado en todos los casos, menos cuando el derecho abdicado es de aquellos que se constituyen por sentencia judicial o acto de autoridad, como veremos. La renuncia o abdicación es posible en relación con preexistentes derechos reales renunciables del testador, que además deben ser transmisibles, porque la renuncia por medio de un testamento de aquellos que se extinguen por la muerte de su titular y que son por ello intransmisibles, como el usufructo, el uso y la habitación, además de superflua e inútil, no vale por falta de objeto.

a) Una servidumbre se extingue si el testador libera directamente al fundo sirviente de un tercero, de la servidumbre que sobre él había en beneficio de un predio dominante suyo, como cuando dice: "Libero a tal fundo de Ticio de la servidumbre de paso que lo grava en beneficio de tal

${ }^{23}$ En la ley $\mathrm{N}^{\circ} 17.336$, sobre propiedad intelectual, no está dicho que el derecho moral de autor sea irrenunciable, aunque tal vez pueda esto entenderse bajo la idea de ser inalienable ese derecho (artículo 16). Pero se llega a la misma conclusión debido a que su fuente es un hecho, la creación de la obra (artículo 1), y el autor no podría abdicar de ese hecho, vale decir, del de dejar de ser autor, merced a un acto jurídico. Se puede aplicar, mutatis mutandis, lo que los romanos decían del heredero: una vez autor, siempre autor.

${ }^{24}$ Tratan esta materia Domínguez Benavente, Ramón - Domínguez Águila, Ramón, Derecho sucesorio (2a edición, Santiago, Editorial Jurídica de Chile, 1998), II, párr. 803, pp. 793-794, pero limitadamente a la hipoteca, la prenda y las servidumbres. 
fundo mío", y el efecto extintivo se produce ipso iure. Beneficiario de este legado es el dueńo del predio sirviente.

El Código nada dice sobre el legado real, pero es evidente su procedencia (artículo 1069 inciso $1^{\circ} \mathrm{CC}$.).

b) Un testador que sea acreedor prendario o hipotecario, vale decir, titular del respectivo derecho real, podría válidamente disponer, en términos directos, la remisión de su prenda o hipoteca, diciendo, por ejemplo: "Remito la prenda (o remito o cancelo la hipoteca) que tengo sobre tal objeto mueble (o inmueble si es hipoteca) de Ticio". El derecho real de prenda se extingue directamente y los herederos deben devolver la prenda al pignorante, que desde la adquisición de eficacia por el legado, ya no está más en caución. En lo relativo a la hipoteca es, por cierto, necesario que la escritura del testamento cubra los requisitos de una escritura pública para que se inscriba la cancelación y se tome razón de ella al margen de su inscripción (artículo 2434 inciso $4^{\circ}$ CC.) ${ }^{25}$. Lo propio cabe decir si se trata de una prenda sin desplazamiento.

Igual a como ocurre entre vivos, en que la remisión de la prenda o hipoteca no acarrea la extinción por remisión de la deuda que ellas garantizaban (artículo 1654 CC.), la remisión por legado de una u otra no implica la remisión de la deuda que caucionaban, la cual permanece en la herencia, y se transmite según las reglas generales, aunque desprovista de garantía. De ello trata, aunque en otro contexto, el artículo 1128 CC., que puede ser generalizado.

En todos los casos, como legatario debe ser considerado el que constituyó la caución, quien, con la abdicación, ve liberada la cosa suya en que aquélla recaía.

c) También un censualista podría remitir por legado el censo al censuario, que sería, pues el legatario (artículo 2043 CC.: "De todo censo [...] podrá disponer el censualista [...] por testamento").

d) En relación con el derecho real de herencia, se pregunta si puede el testador extinguir por legado un derecho tal que le pertenezca, vale decir, sobre una herencia a él deferida y ya aceptada al momento de testar, que aún permanece indivisa al morir, de modo que, en principio, transmite. La respuesta es negativa. El derecho real de herencia puede ser repudiado; pero una vez aceptado ya no es posible revocarlo (artículo 1234 CC.) ni, por ende, abdicarlo; y una disposición testamentaria que lo hiciera no valdría ${ }^{26}$.

${ }^{25}$ De no cumplir tales requisitos, creemos que el legado se convierte en obligacional y fuerza a los herederos a extender entre vivos la escritura de cancelación

${ }^{26} \mathrm{Si} \mathrm{el} \mathrm{testador} \mathrm{aun} \mathrm{no} \mathrm{había} \mathrm{aceptado} \mathrm{la} \mathrm{herencia} \mathrm{al} \mathrm{testar} \mathrm{(ni} \mathrm{al} \mathrm{morir),} \mathrm{no} \mathrm{podría}$ ordenar por legado que su heredero la repudie, porque así vulneraría el derecho de 
e) El titular de un derecho real minero o de un derecho de aprovechamiento de aguas o de un derecho de patente industrial podría formular testamentariamente una renuncia a su derecho ${ }^{27}$. Pero tal acto no es un legado. La extinción del derecho no tiene un tercer beneficiario que pueda ser considerado como legatario.

\section{LAS OBLIGACIONES NACIDAS DE LEGADO FRENTE A LOS DISTINTOS TIPOS DE OBLIGACIÓN}

El Código Civil conoce y regula diversas clases de obligación en los títulos $3^{\circ}$ a $11^{\circ}$ de su libro IV. Ellas son: civiles y naturales (tít. $3^{\circ}$ ), condicionales y modales (tít. $4^{\circ}$ ), a plazo (tít. $5^{\circ}$ ), alternativas (tít. $6^{\circ}$ ), facultativas (tít. $7^{\circ}$ ), de género (tít. $8^{\circ}$ ) y especie, mancomunadas y solidarias (tít. $9^{\circ}$ ), divisibles e indivisibles (tít. $10^{\circ}$ ), con cláusula penal (tít. $11^{\circ}$ ). De la definición de contrato contenida en el artículo 1438 fluye la clasificación en obligaciones de dar, hacer y no hacer, que viene generalizada en el título $12^{\text {a }}$ del libro IV e independizada de la fuente contractual. La doctrina añade otras clasificaciones, pero nos abstendremos de considerarlas aquí.

En esta materia, el Código asume un criterio funcional de exposición: las diferentes clases de obligación que trata son independientes de la estructura de la causa o fuentes que las origina; así que va supuesto el hecho de que todas las obligaciones, cualquiera que sea su fuente, pueden asumir cualesquiera de las clases tratadas. Sin embargo, el análisis revela que estas no son aplicables siempre a las obligaciones nacidas de las cinco causas o fuentes que reconoce el Código. De hecho, ellas son universalmente aplicables sólo a las obligaciones contractuales (y aún así con limitaciones) y a las originadas en un legado. Las demás admiten únicamente algunas de las clasificaciones.

\section{Obligaciones de dar, hacer o no hacer.}

La distinción de prestaciones de dar, hacer o no hacer, que, según la presencia de una u otra, determina los correspondientes tres tipos de obligación (artículos 1548, 1553 y 1555; cfr. con el 1438 CC.) no cabe indistintamente en obligaciones emanadas de cualquier fuente. Aquellas provenientes de delito y cuasidelito son siempre de dar (y además sólo dinero como indemnización); algo semejante acaece en las obligaciones

transmisión (artículo 957 CC.) a favor de ese heredero, según el cual él puede libremente aceptar o repudiar la herencia deferida a su causante.

${ }^{27}$ Como el inciso $2^{\circ}$ del artículo $162 \mathrm{CM}$. exige escritura pública para la renuncia, el legado en función de renuncia vale si el testamento que lo contiene reúne los requisitos de la escritura pública, según el artículo 403 COT. 
cuasicontractuales, que no provengan de un legado, en que su prestación de dar puede, empero, quedar referida a una especie, como en la restitución de la indebidamente recibida en pago. Las obligaciones legales generalmente son de dar dinero, aunque excepcionalmente de dar derechos reales de usufructo, uso o habitación, como puede ser según el artículo 65 No 2 de la Ley No 19.947 sobre matrimonio civil, a título de compensación económica en caso de nulidad de un matrimonio o de divorcio; o según el artículo 9 de la Ley No 14.908, en el texto fijado por el artículo 7 del DFL. No 1 del Ministerio de Justicia (DO. de 30 mayo de 2000), que autoriza el pago de pensiones alimenticias con la dación de tales derechos. De esta forma, la posibilidad de que las obligaciones pueden ser indistintamente de dar, hacer o no hacer es propia de los contratos; pero también de los legados de efecto obligacional. Aquí bastarán algunos ejemplos.

Si un testador dispone así: "Lego 1.000 a Ticio", este legado crea una obligación de dar un género determinado (dinero) a favor del legatario. Si dispone, en cambio: "Que mi heredero dé su fundo Corneliano a Ticio" (artículo 1107 CC.), él ahora crea una obligación de dar el dominio de cierta especie por el heredero gravado, que es el deudor, al legatario, su acreedor; y si dice: "Que mi heredero quede obligado a dar el usufructo de su fundo Corneliano a Ticio", ahora la obligación es de dar un derecho real. Cuando el legado vaya dispuesto bajo esta otra fórmula: "Que mi heredero compre a Cayo su fundo Corneliano y que, comprado, se lo dé a Ticio" (artículo 1106 CC.), entonces la obligación impuesta es la de celebrar el contrato de compra y es de hacer (aunque después se añada la de dar el objeto comprado). Cuando, en fin, el testador declara: "Que mi heredero permita a mi vecino Ticio pasar por mi fundo Corneliano" (que no es de dar la servidumbre de paso, sino de meramente permitir de hecho el paso), la obligación que grava al heredero es de nada hacer para impedir que el legatario pase por el fundo, vale decir, de no hacer.

Estos sencillos ejemplos pueden multiplicarse muchas veces bajo diversas formas; pero ellos ponen suficientemente en manifiesto la versatilidad de un legado de efectos obligacionales para admitir toda clase de prestaciones; que es paralela a aquella del contrato.

\section{Obligaciones civiles y naturales.}

a) Las obligaciones naturales obedecen a un fenómeno extrínseco y anómalo que afecta a las obligaciones regulares, o sea, a las civiles. La distinción, por ende, no es, propiamente hablando, una clasificación, pero ya el Código presenta como tal la dualidad y la doctrina sigue su postura.

Ocurre que en ciertos casos una obligación llamada a nacer regularmente, o nacida como tal, de modo de poderse exigir su cumplimiento, 
se vea afectada por ciertas circunstancias que hacen que ese efecto regular no pueda tener lugar, aunque, cumplidas, el acreedor queda autorizado a retener lo dado o pagado por ellas. Este fenómeno se da al menos en los casos establecidos en el artículo 1470 inciso $4^{\circ} \mathrm{CC}$., en sus números $1^{\circ} \mathrm{al}$ $4^{\circ}$, a los que nos limitaremos, no bien se discuta si existen otros ${ }^{28}$. Todos ellos son perfectamente aplicables a las obligaciones nacidas de un legado de efectos personales.

b) El punto es evidente, porque tales obligaciones, que indiscutiblemente son civiles, están expuestas a los eventos descritos en dichos números del artículo 1470 CC.; pero, como no suele tenerse en cuenta, le pasaremos una revista expeditiva.

La obligación legataria natural del $\mathrm{N}^{\circ} 1$ no se da cuanto sea el testador, sino el obligado a cumplir un legado de efectos obligacionales el que se encuentra en el evento descrito ahí. Como es sabido, por regla general son obligados a cumplir un legado todos los herederos o algunos de ellos, a prorrata de sus cuotas hereditarias o en las porciones fijadas por el testador, o bien un legatario (artículo 1360 CC.). Si acaece, pues, que una de las personas designadas acepta su propia asignación, empieza a quedar obligada al cumplimiento de los legado cuyo pago le afecta. En la concepción del Código, con la aceptación ha tenido lugar un cuasicontrato (artículo 1437 CC.). Pero si ella es persona de suficiente juicio y discernimiento, mas no capaz de obligarse según las leyes, como el menor adulto, la obligación de pagar el legado contraída es meramente natural ${ }^{29}$.

El caso del $\mathrm{N}^{\circ} 2$ del artículo 1470 inciso $4^{\circ} \mathrm{CC}$. puede ser de evidente ocurrencia con respecto a la obligación de cumplir un legado, que, como cualquier otra, también está sujeta a prescripción extintiva.

El caso del $\mathrm{N}^{\circ} 3$ de aquella disposición incluso contiene un ejemplo que atañe directamente a nuestra materia. Dice: "Las [obligaciones] que

${ }^{28}$ Sobre el punto: Abeliuk Manasevich, René, Las obligaciones, cit. (n. 6), I, números 328-333, pp. 272-276.

${ }^{29}$ Hay una leve dificultad en este raciocinio. El artículo 1225 inciso $3^{\circ}$ CC. prohíbe a las personas que no tienen la libre administración de sus bienes (cual es el caso del menor adulto) aceptar por sí solas una asignación a ellas deferida, aun con beneficio de inventario. Así que la aceptación de tales personas por sí solas (vale decir, sin la intervención de su representante legal), porque constituye un acto prohibido por las leyes, adolece de objeto ilícito y es nula absolutamente (artículos 1466 parte final por analogía, y 1682 CC.). En otras palabras, la aceptación de un menor adulto por sí solo no sigue la regla general de ser tan sólo nula relativamente (artículo 1682 CC.), en contra de lo que sostiene habitualmente la doctrina [véanse, por todos: Domínguez Benavente, R. - Domínguez Águila, R., Derecho sucesorio, cit. (n. 24), I, núm. 163, p. 192]. Ahora bien, que la aceptación sea nula absolutamente, eso no impide que la obligación se convierta en natural. 
proceden de actos a que faltan las solemnidades que la ley exige para que produzcan efectos civiles; como la de pagar un legado, impuesto por un testamento que no se ha otorgado en la forma debida".

El caso del $\mathrm{N}^{\circ} 4$ de la norma en examen también es de ocurrencia manifiesta, aunque más difícil, en tema de obligaciones legatarias, porque la prueba de haber habido un legado es el testamento de que supuestamente emana y entonces "falta de prueba" significa falta de testamento y tal defecto implica, a su vez, ausencia de legado, porque un legado, salvo el caso de los legados legales ${ }^{30}$, sólo puede ser dispuesto en un testamento.

\section{Obligaciones condicionales.}

a) Las obligaciones nacidas de cuasicontrato que no sean de aquella que se basan en un legado aceptado, de delitos y de cuasidelitos no pueden estar sometidas a condiciones suspensivas ni resolutorias. Las legales teóricamente pueden quedar sujetas a condición suspensiva, si la ley que las crea impone cierta condición para su exigibilidad, en el entendido de no deberse confundir los presupuestos que ella establezca para el nacimiento de la obligación que crea con condiciones impuestas a ésta. La obligación legal de alimentar a los descendientes (artículo $321 \mathrm{~N}^{\circ} 2$ CC.), no está sujeta a la condición de ser descendiente el alimentario ni a la de carecer él mismo de medios de subsistencia, que alcancen para vivir de un modo correspondiente a su posición social (artículo 330 CC.). Ambos hechos son sólo presupuestos de existencia de la obligación (que, por lo demás, miran al pasado o al presente). Ahora bien, si suponemos un ordenamiento que establezca que la obligación de prestar alimentos queda supeditada a la decisión del alimentario de no vivir en casa del alimentante, tal sí que sería una verdadera condición (legal) de la obligación. Pero que la norma creadora de obligaciones legales imponga verdaderas condiciones a la obligación que crea es un evento de rarísima ocurrencia. Menos raro puede ser la imposición de condiciones resolutorias, para que, por su cumplimiento, se extinga la obligación legal. De hecho, en la misma obligación legal de prestar alimentos, la cual, según el artículo 332 inciso $1^{\circ} \mathrm{CC}$., se entiende vigente para toda la vida del alimentario "continuando las circunstancias que legitimaron la demanda", puede verse una condición resolutoria en esta última exigencia, de modo de construirse la obligación como extinguible si se cumple el hecho futuro e incierto de empezar el alimentario a tener medios de subsistencia que alcancen para vivir de un modo correspon-

\footnotetext{
${ }^{30}$ Sobre la noción de legado legal, véase: Guzmán Brito, Alejandro, El concepto de legado en el Derecho civil chileno, en Revista de Derecho 21 (Universidad Austral de Chile, diciembre de 2008) 2, cap. IV, pp. 60-64.
} 
diente a su posición social. Claro que también podría mirarse el caso de otro modo, a saber, que empezar el alimentario a tener medios propios de subsistencia implica el cese de uno de los presupuestos de la obligación, que también, por ende, debe cesar.

En tales circunstancias, restan los contratos, en los cuales ciertamente pueden insertarse condiciones tanto suspensivas como resolutorias. Al tema está principalmente dedicado el título $4^{\circ}$ del libro IV CC. y, subsidiariamente, merced a lo dispuesto por el artículo 1493 CC., el título $4^{\circ}$ de su libro III, lo que en realidad debe entenderse como una remisión a los $\$ \$$ 2: De las asignaciones testamentarias condicionales, y 3: De las asignaciones testamentarias a día (en cuanto algunas de éstas son condicionales), de ese título.

b) Pero no en todos los contratos caben condiciones suspensivas y resolutorias. Desde luego no en los reales, salvo en algunas donaciones que tienen este carácter ${ }^{31}$. La razón es que una condición que suspenda la obligación de restituir es incompatible con la entrega o tradición que perfecciona el acto. Aunque, pues, en un mutuo, por ejemplo, se ejecute la entrega de una cantidad para que se haga del que la recibe a título de mutuo, desde que se cumpla cierta condición, sea que se cumpla ésta, sea que no, el receptor ya la recibió y está obligado a restituirla. Tratándose de condiciones resolutorias, su aposición en los actos reales pueden desvirtuarlos. Si se inserta, por ejemplo, en un mutuo, para que cese la obligación de restituir si se cumple tal condición, esto implica la conversión del mutuo en una donación sometida a condición suspensiva. Lo dicho para el mutuo, vale para los demás contratos reales que no sean la donación real.

La condición, pues, tiene un campo de aplicación propio en las obligaciones de los contratos consensuales y solemnes unilaterales, y también en los bilaterales, siempre que aquélla afecte a todo el contrato y no sólo a la obligación de una de sus partes. $\mathrm{Si}$, en efecto, se celebra una compraventa, por ejemplo, en que se acuerda, no para el contrato mismo, sino únicamente para la obligación de entregar la cosa, que ésta quede sujeta a determinada condición suspensiva, de modo que el comprador debe pagar el precio en todo evento, ese acto no es una compraventa, sino probablemente una apuesta. Por el contrario, en algunos contratos bilaterales (solemnes), como el de promesa de contrato, la inserción de una condición es una de las alternativas necesarias (artículo $1554 \mathrm{~N}^{\circ} 3$ ). En la práctica es frecuente

${ }^{31}$ Sobre la posibilidad (restringida) de imponer condiciones en una donación real, véase: Guzmán Brito, Alejandro, De las donaciones entre vivos. Conceptos y tipos (Santiago, LexisNexis, 2005), §30, pp. 240-247. 
en las compraventas; menos en otros; pero siempre posible en teoría, con las limitaciones dichas.

c) A esta aplicabilidad de la disciplina de las condiciones en los contratos consensuales y solemnes corresponde su plena aplicabilidad en los legados (y en la institución de heredero y en otras asignaciones). El Código dedica al régimen de las condiciones testamentarias el $\$ 2$ y parte del $\$ 3$ del título $4^{\circ}$ de su libro III; y, según lo señalado por el inciso $2^{\text {a }}$ de su artículo 1070 , también el título $4^{\mathrm{a}}$ de su libro IV, en lo aplicable y no modificado por los primeramente mencionados.

\section{Obligaciones a plazo.}

Las obligaciones cuasicontractuales, que no se funden en un legado aceptado, las delictuales y las cuasidelictuales, por su naturaleza, no admiten nacer bajo plazo; aunque, nacidas, admitan el engarce convencional de un plazo para su pago. Nada impide que las legales puedan estar sujetas a un plazo para su exigibilidad, impuesto por la misma ley que las crea, aunque ello no sea del todo frecuente. Por el contrario, la posibilidad de un pacto de plazo en su origen es regla general en los contratos, bajo la forma regulada en el título $5^{\circ}$ del libro IV CC. y, por mandato del artículo 1498 CC., en el título $4^{\circ}$ de su libro III, aunque la referencia es concretamente al $\$ 3$ de ese título, en cuanto ahí se trata de las asignaciones testamentarias a día en que el día constituye plazo y no condición.

También en los legados (y demás asignaciones por causa de muerte, salvo en las legítimas) es normal la posibilidad de imponerles plazos. Al plazo en los legados va dedicada una parte del $\$ 3$ del título $4^{\circ}$ de su libro III; y, en lo aplicable, el título $5^{\circ}$ del libro IV, según disposición del artículo 1080 CC.

\section{Obligaciones modales.}

a) De estar a la rúbrica del título $4^{\circ}$ : De las obligaciones condicionales y modales, del libro IV CC. y a su artículo 1493, las obligaciones sujetas a modo, o modales, son posibles con respecto a las nacidas de cualquier fuente; pero es claro que el modo no puede tener lugar en las obligaciones cuasicontractuales, que no estén fundadas en un legado aceptado, delictuales ni cuasidelictuales y sólo teórica aunque raramente en las legales. También puede concebirse su aplicación en las contractuales, aunque de manera asaz insólita en aquellos contratos de libre discusión, salvo en las donaciones (si es que podemos considerarla de libre discusión), que, por 
lo demás, cuando lo portan, están mencionadas en el artículo 1405 CC. ${ }^{32}$ y se rigen sin más por el $\$ 4$ del título $4^{a}$ del libro III CC.

La definición de modo ofrecida por el artículo 1089 CC. -en realidad más preocupado de diferenciar al modo de la condición que de definir aquél- reza: "Si se asigna algo a una persona para que lo tenga por suyo con la obligación de aplicarlo a un fin especial, como el de hacer ciertas obras o sujetarse a ciertas cargas, esta aplicación es un modo y no una condición suspensiva. El modo, por consiguiente, no suspende la adquisición de la cosa asignada". La norma exige que cierto objeto vaya a la propiedad de una de las partes ("para que lo tenga por suyo"), precisamente de aquella gravada con el modo. De acuerdo con esto, la aplicación de la figura a los contratos sólo cabría en aquellos que son títulos traslativos del dominio. Pero es en ellos, salvo en la donación, en donde más difícil es que tenga lugar un modo. Una compraventa, con el modo impuesto al vendedor o al comprador de aplicar el dinero del precio o la cosa a un fin especial no es muy arreglada a la libertad del mercado cuyo principal motor es la compraventa. Tampoco en la permuta es fácilmente concebible de hecho un modo. Por el contrario, en contratos de mera tenencia, como el arrendamiento de cosas o el comodato es más factible su presencia. Un arrendador o un comodante podrían tener interés en que la cosa que dan en arriendo o comodato deba ser aplicado a un fin especial. Pero, de acuerdo con los extremos del artículo 1089 CC., tal fin especial no es un modo, porque el gravado no tiene la cosa como suya, es decir, no se hace dueño de ella. Lo cual no significa que sea jurídicamente imposible una cláusula en tales contratos, que obligue a aplicar la cosa a un fin especial. De hecho, son frecuentes en la práctica algunas en que se impone a la contraparte una obligación de no hacer, consistente en no aplicar la cosa a determinadas actividades.

Sin embargo, hay un contrato traslativo de dominio, como el mutuo, en que también se concibe algo parecido a un modo: la doctrina italiana lo denomina "mutuo di scopo", o sea, mutuo "de fin" (mejor fuere: "con un fin" $)^{33} ; \mathrm{y}$ consiste en imponer un destino especial al dinero prestado, que el mutuario está obligado a observar. Tal acaece, empero, no en los mutuos del tráfico ordinario, ni entre particulares ni siquiera en aquellos bancarios frecuentemente denominados "créditos de consumo", sino en los mutuos que hacen parte de algún programa, generalmente de carácter masivo, como cuando el Estado, a través de alguna institución pública, pero también

${ }^{32}$ Sobre las donaciones modales: GuZmán Brito, A., De las donaciones, cit. (n. $31), \$ 28$, pp. 229 ss.

${ }^{33}$ Sobre él, puede verse: Zimatore, Attilio, Il mutuo di scopo. Problemi generali (Padova, Cedam, 1985). 
las instituciones privadas, prestan dinero para la vivienda, para la compra de vehículos o equipos, para el financiamiento de los estudios y otros. En tales casos, acontece que el mutuario ni siquiera ve pasar por sus manos el dinero, que va directamente a la institución pública o privada vendedora del objeto de que se trate o prestadora del servicio educacional.

Se ve, pues, que la doctrina del modo aplicada a los contratos ofrece limitaciones y especialidades, que no permiten sostener que aquella sea de normal aplicación en ellos. De hecho, pueden reemplazarlo figuras como la estipulación a favor de terceros o la propiedad fiduciaria.

b) Por el contrario, el modo es una figura, aunque accidental, posible con generalidad y sin restricción en los legados (y en las demás asignaciones por causa de muerte patrimoniales que no sean las legítimas, y en la donación). A ellos, pues, también son directamente aplicables las normas del $₫ 4$ del título $4^{\circ}$ del libro III. CC.

\section{Obligaciones alternativas.}

a) La alternatividad obligacional no es posible en los cuasicontratos, que no sean el legado aceptado, los delitos ni los cuasidelitos. La ley, al crear obligaciones, podría imponerles alternatividad; pero no conocemos algún ejemplo de tal posibilidad teórica.

Ella en cambio, es propia de los contratos, en los términos del título $6^{\circ}$ del libro IV CC.; aunque no de todos. No desde luego en los reales, excepto en la donación real. La obligación restitutoria, propia de estos contratos, establecida como alternativa, modificaría la naturaleza de los mismos. Supóngase el mutuo de una cantidad de dinero convenido para que el mutuario devuelva otro tanto de dinero o una mesa de plata; lo cual es, por supuesto, posible y válido; pero no es mutuo, sino venta de la mesa con pacto de su retrocompra por el vendedor. Si suponemos el comodato de una mesa de plata para que el comodatario restituya la misma mesa o cierta cantidad de dinero, o bien la mesa o tal caballo purasangre, entonces tenemos una venta o una permuta con pactum displicentiae ${ }^{34}$. En los contratos consensuales y solemnes, que contengan obligaciones restitutorias, la alternatividad en éstas también puede modificar la naturaleza de los

${ }^{34}$ Como se sabe, tal pacto ańadido a una compraventa autoriza al comprador para resolver el contrato, devolviendo la cosa y recobrando el precio. Su función es que la cosa comprada quede "a prueba" del comprador, de modo que, si no le place, pueda devolverla. El Código trata de semejante contrato en su artículo 1823, aunque lo mira como sometido a condición suspensiva. Ahora bien, analizadas a fondo las figuras que hemos propuesto como ejemplos, es tal lo que acaece, con la modificación de que el precio (el dinero o la otra cosa) no fueron pagados al principio, pues se prevé su pago al final, según la decisión del comprador. 
mismos. Asimismo en otros casos, cuando la alternatividad se imponga a obligaciones no restitutorias, pero cuya prestación esté tipificada en la ley. Si, por ejemplo, se conviene en la compraventa de una mesa de plata que su precio fuera cierta cantidad de dinero o un caballo purasangre, es que se introdujo un elemento permutatorio en tal compraventa. El análisis puede revelar fenómenos semejantes en otros contratos. Pero nos atrevemos a reducir las posibilidades de que no se desvirtúe cualquier contrato a esta regla: la alternatividad es posible cuando, multiplicada la prestación contractual bajo forma alternativa, cada una de las alternativas mirada individualmente y considerada como única, es admisible en ese contrato sin que se altere su consistencia jurídica. Tal ocurre, por ejemplo, si se vende por cierta cantidad de dinero una mesa de plata o un caballo purasangre. La convención consensual de cambiar obligacionalmente dinero por una mesa de plata es compraventa; también lo es aquella de intercambiar dinero por un caballo purasangre. En consecuencia, la de intercambiar dinero por una mesa o por un caballo sigue siendo compraventa. De hecho, es lo que reconoce para la cosa el artículo 1807 inciso $3^{\circ}$ CC.: "Puede [la venta] tener por objeto dos o más cosas alternativas". Por supuesto, la compraventa de una mesa de plata por una cantidad de dinero o un caballo purasangre ya contiene un elemento permutatorio que no hace aplicable la citada disposición y obliga a un análisis más complejo de la figura.

De esta manera, pues, supuesto el cumplimiento de la regla antes propuesta, la alternatividad obligacional es posible en los contratos. Entonces se hace aplicable el título $6^{\circ}$ del libro IV CC.

b) Ahora bien, ella es posible sin restricciones en los legados. El artículo 1117 CC. contiene el régimen: "Si la elección de una cosa entre muchas se diere expresamente a la persona obligada o al legatario, podrá respectivamente aquél o éste ofrecer o elegir a su arbitrio. [inciso $2^{\circ}$ ] Si el testador cometiere la elección a tercera persona, podrá ésta elegir a su arbitrio, y si no cumpliere su encargo dentro del tiempo señalado por el testador o en su defecto por el juez, tendrá lugar la regla del artículo $1114^{35}$. [inciso $3^{\circ}$ ] Hecha una vez la elección, no habrá lugar a hacerla de nuevo, sino por causa de engaño o dolo". Debe tenerse presente que la disposición se aplica a los legados de efecto real y obligacional (aunque aquí sólo interesan estos últimos). Si el testador dice: "Que mi heredero quede obligado a dar 1.000 o una mesa de plata a Ticio, a elección de éste", tenemos un legado alternativo de efecto obligacional.

${ }^{35}$ Artículo 1114 CC.: "Si de muchas especies que existan en el patrimonio del testador, se legare una sin decir cuál, se deberá una especie de mediana calidad o valor entre las comprendidas en el legado" 
Si dice: "Lego tal mesa de plata o tal caballo purasangre a Ticio, a elección de éste", el legado es también alternativo, pero de efecto real.

La norma transcrita más supone que establece la posibilidad de legados de objeto alternativo; y su fin es imponer ciertas reglas especiales. En consecuencia, fuera del dispositivo de ese artículo, los legados obligaciones de objeto alternativo se rigen en todo por las normas del título $6^{\circ}$ del libro IV CC., lo mismo que si la alternatividad estuviere contenida en un contrato que la admita.

\section{Obligaciones facultativas.}

a) La facultatividad obligacional, tratada en el título $7^{\circ}$ del libro IV CC., no es procedente en el origen de las obligaciones cuasicontractuales, que no sean de legado aceptado, ni en las delictuales ni cuasidelictuales; aunque, una vez creadas, las partes puedan modificarla convencionalmente en el sentido de la facultatividad. En las legales es teóricamente posible, pero no conocemos ejemplos.

Entre vivos, pues, la facultatividad es propia de las obligaciones contractuales, siempre que ella no altere la naturaleza del contrato que es causa o fuente de la obligación; como acaecería en los que contienen obligaciones restitutorias. Así, por ejemplo, en el comodato, cuando se diera al comodatario la facultad de sustituir la restitución de la cosa comodada por la tradición de una cantidad de dinero o de otra cosa; pues tal es una compraventa o una permuta, nuevamente con pactum displicentiae. $\mathrm{Al}$ respecto podemos establecer una regla semejante a la sentada para las obligaciones alternativas. Si la prestación obligada y la no obligada que hacen parte de la estructura facultativa admiten ser insertadas individualmente en el contrato fuente de que se trate sin alteración de su naturaleza, entonces él admite ser definido con obligación facultativa; no en caso contrario. Así, por ejemplo, es posible la venta con facultatividad: se conviene en tener por vendida tal especie por 1.000, pero que el vendedor podrá entregar otra distinta en sustitución. Como cualesquiera de ambas especies hubieran podido ser objeto individual de una compraventa, al ser deducidas ahora en relación de facultatividad en ella, la compraventa no pierde su naturaleza. Lo contrario, empero, no fuere posible, como si se conviene en tener comprada cierta especie por 1.000, y que el comprador pueda pagar el precio con otra; pues en tal caso se abre la posibilidad de que el contrato devenga en permuta; sin que por ello sea inválida la cláusula de facultatividad, cuyos efectos estructurales en el contrato, empero, deben ser revisados.

La facultatividad también causa problemas en los contratos bilaterales de mera tenencia. Supóngase un arrendamiento, en que se concede al 
arrendatario la facultad de restituir otra cosa distinta a la arrendada (sin perjuicio de pagar la renta, como en todo contrato de esta especie); y nadie dejará de ver que en tal figura también hay envuelto un elemento permutatorio unido a una compraventa.

Las dificultades que origina la facultatividad derivan de su generalización a partir de la única estructura en que el Derecho romano la veía funcionar: la stipulatio. La facultatividad es, en realidad el fenómeno que se produce cuando se estipula así: "Si no me dieres el fundo Corneliano, ¿prometes darme 1.000? ¡Prometo!” 36 El promitente sólo debe 1.000 y lo único que el estipulante puede reclamar es esa cantidad, porque exclusivamente ella fue objeto de lo prometido ${ }^{37}$. Como el fundo, en cambio, no lo fue, no es debido por el promitente ni reclamable por el estipulante. Ahora bien, si el estipulante da el fundo, ya no debe pagar los 1.000. Dar el fundo y no pagar los 1.000 o pagar estos (sin dar el fundo) queda al arbitrio del deudor de los 1.000. Esta doble opción fue considerada como materia de una "facultad" del deudor por los intérpretes medievales, de donde que hablaran de "obligación facultativa". En consecuencia, estamos ante el caso de una obligación que "tiene por objeto una cosa determinada [los 1.000], pero concediéndose al deudor la facultad de pagar con esa cosa o con otra que se designa" [el fundo], como reza el artículo 1505 CC. La clave de la figura está, como se ve, en que la única obligación generada está sometida al hecho futuro e incierto de no darse otra cosa (el fundo), o sea, a una condición. Por cierto, este esquema formal sólo se entiende cabalmente cuando se atiende a la operación causal de la estipulación, que puede ser una donación, si el donante del fundo quiere reservarse hasta el último minuto el poder de sustituir el objeto donado por una cantidad de dinero; o una compraventa, si el vendedor no está seguro de poder cumplir con la entrega del fundo y también quiere reservarse las posibilidad de poder devolver el precio ya recibido; o bien para operar lo que nosotros llamamos "cláusula penal”, sobre la base de que, por ejemplo, lo vendido haya sido el fundo y que la cantidad de dinero prometida en la estipulación sea muy alta: de esta manera, si el vendedor no da el fundo (vendido), lo cual queda en su facultad hacer, debe pagar una suma muy onerosa (que puede incluir el monto del precio a título de devolución, si ya había sido entregado). En tales condiciones, la facultatividad no es un carácter que pueda imponerse a cualquier estructura obligacional, sino sólo a la de la estipulación (y al legado, como veremos); si bien, como ella

${ }^{36}$ Dig. 44,7,44,5.

${ }^{37}$ Artículo 1506 CC.: "En la obligación facultativa el acreedor no tiene derecho para pedir otra cosa que aquella a que el deudor es directamente obligado [...]”. 
necesariamente debe estar superpuesta a cualquier negocio causal, por su vía indirecta queda impuesta a éste, sin desvirtuarlo. La historia posterior, en lo que a nuestro tema interesa, puede resumirse en dos frases: desaparecida la estipulación como forma negocial, se conservó, entre otras tantas, la función facultativa que ella era capaz de cumplir, pero endosada a los negocios causales directamente y de un modo general, con lo cual se hizo algo ininteligible.

b) En cierta medida, lo que la stipulatio es entre vivos, lo es por causa de muerte el legado. No es extraño entonces que la facultatividad también sea posible en ellos. En el Derecho moderno es incluso más propia de los legados que de los contratos, por las razones explicadas precedentemente ${ }^{38}$. Nada queda desvirtuado si el testador dice: "Lego 1.000 a Ticio y ordeno que este legado sea pagado por mi heredero, con la facultad de dar tal mesa de plata en sustitución”. ¿Qué razón puede tener semejante asignación? Dos al menos. Si el testador está seguro que la mesa hará parte de su acervo sucesorio al morir, la explicación puede ser que los 1.000 (bajo el supuesto de que sea una cantidad alta con respecto al valor de la mesa) actúan como pena por no dar la mesa de plata el heredero al legatario, que es lo que el testador quiso realmente legar: es claro que el heredero debería preferir dar la mesa, pero el testador quiso reservarle también la posibilidad de conservarla para sí, sólo que con un cierto sacrificio pecuniario. También puede explicarse como previsión de que la mesa no haya de estar en el acervo al morir, de modo que, si se legara directamente, por aquello quedare revocada la asignación (artículo 1135 CC.); entonces el testador, en vez de atribuirla, lega dinero; sólo que, si fallare su previsión y la mesa permanece en el acervo, el heredero podrá sustituir los 1.000 por la mesa.

Se observará que el legado del ejemplo precedente puede ser reconducido a este esquema: "Si mi heredero no diere tal mesa de plata a Ticio, lego a éste 1.000".

8. Obligaciones de género y de especie.

a) Esta distinción pertenece al Derecho general de las obligaciones. Atendida la frecuencia de las obligaciones de cantidades de dinero en ese Derecho, basta, para comprobarlo, tener presente que tales obligaciones son precisamente de género. Por supuesto, se aplica a cosas distintas al dinero que también pueden ser consideradas genéricamente; y cobran especial

\footnotetext{
${ }^{38}$ Resulta muy significativo que, para ilustrar el concepto de obligación facultativa, los autores suelan ofrecer ejemplos de legados; por todos: Abeliuk Manasevich, Las obligaciones, cit. (n. 6), I, núm. 377, p. 319; Peñailillo, Arévalo, Daniel, Obligaciones. Teoría general y clasificaciones. La resolución por incumplimiento (Santiago, Editorial Jurídica de Chile, 2003), p. 220 n. 321.
} 
relevancia en la compraventa de géneros, en todos los contratos con precio en dinero y en el mutuo. Para el Código, la presencia de una asignación de género define todo un tipo de legado, en los términos de los artículos 951 inciso $3^{\circ}$ y 1066 inciso $1^{\circ}$, que la doctrina denomina "legado de género". A él se refiere, por lo demás, el artículo 1115 CC.

Otro tanto no cabe decir para las obligaciones de especie, que quedan o tienden a quedar limitadas a las de origen contractual, pues tienen escaso lugar en las cuasicontractuales, que no sean de legado ${ }^{39}$, ni en las delictuales ni cuasidelictuales. Escasamente y, por excepción, en las legales. Su campo propio es, pues, el de las obligaciones contractuales y hay muchos contratos en que alguna de sus prestaciones tiene tipificada la de especie; así, por ejemplo, el comodato, el depósito, la prenda con desplazamiento, la hipoteca, el censo, el arrendamiento de cosas. Los hay, como la compraventa, en que la prestación de la parte vendedora puede ser de especie o de género.

b) Ahora bien, en tema de legados, el Código usa el punto de vista de la especie como objeto para definir un segundo tipo de legado sobre ella, así en los artículos 951 inciso $3^{\circ}$, y 1066 inciso $1^{\circ}$, que la doctrina denomina "legado de especie". A él se refiere, por lo demás, diversas disposiciones del $\$ 6$ del título $4^{\circ}$ del libro III CC. El problema está en que la doctrina común considera que los legados de especie no son obligacionales sino reales, vale decir, que atribuyen directamente el dominio al legatario, quien entonces puede ejercer la acción reivindicatoria para satisfacerse. Pero se trata aquella de una indebida reducción de la tipología de los legados. En otro lugar ${ }^{40}$ hemos mostrado cómo es posible que la especie puede ser objeto de un legado de efectos meramente obligacionales, del tipo: "Que mi heredero quede obligado a dar mi fundo Corneliano a Ticio", o bien: "Que mi heredero dé mi fundo Corneliano a Ticio"; o asimismo: "Ordeno a mi heredero dar mi fundo Corneliano a Ticio". En estos casos no hay por qué desconocer la voluntad del testador y convertir estos legados en reales, sólo por el hecho de contener una especie. Al respetarla, lo que debe acaecer es que el heredero se haga deudor de la especie para con el legatario, quien dispone entonces de la actio ex testamento para exigir su pago al deudor. Esto, sin hacer nuevo caudal de que en el Código hay varias hipótesis de legados de especie que no pueden tener efectos sino que obligacionales, como aquel previsto en el artículo 1106, de ordenar el testador que se adquiera una especie ajena para darla al legatario; o

${ }^{39}$ Un ejemplo puede ser la obligación de restituir la especie recibida indebidamente en pago.

${ }^{40}$ Guzmán Brito, A., La tipología de los legados, cit. (n. 9), cap. III, pp. 62-71. 
aquel otro descrito en el artículo 1107, de legar una cosa perteneciente al heredero o a un legatario; etcétera.

No es necesario insistir más sobre esta clara aplicabilidad de la distinción de prestaciones de género y especie a las obligaciones legatarias.

\section{Obligaciones mancomunadas y solidarias.}

a) La posibilidad de deudas y créditos mancomunados es Derecho general de obligaciones, cada vez que muchos contraen cierta obligación para con otro, o uno o muchos para con muchos, en todos los casos si la obligación es sobre un objeto divisible. En tal caso, cada deudor debe pagar y cada acreedor puede cobrar sólo la cuota que le corresponda en el total del objeto debido. Es la regla que sientan los artículos 1511 inciso $1^{\circ}$ y 1526 inciso $1^{\circ} \mathrm{CC}$. La mancomunidad se da incluso en obligaciones legales, como lo muestra el artículo 326 inciso $2^{\circ}$ : si más de una persona están obligadas a dar alimentos por tener un mismo grado de parentesco con el alimentario, o bien por estar afectados por el mismo título "el juez distribuirá la obligación en proporción a sus facultades". Hacen excepción, como se dirá, las obligaciones emanadas de un ilícito cometido por más de uno. Pero debe tenerse presente que una obligación transmisible sobre objeto divisible no mancomunada, por tener a un único sujeto como acreedor o deudor, al convertirse en hereditaria, si hay más de un heredero, se mancomuna entre todos ellos, por división legal, en proporción a sus cuotas hereditarias (1354 inciso $1^{\circ} \mathrm{CC}$.). Esto vale incluso para las obligaciones contraídas por varios al principio en modo solidario, que se hacen mancomunadas por la muerte del acreedor o del deudor, porque, como es sabido, la solidaridad no se transmite a los herederos (artículo 1523 CC.). Así que, por ejemplo, si dos han cometido un delito y son condenados solidariamente al pago de la indemnización, muerto uno de ellos, que dejó dos herederos por partes iguales, el acreedor puede dirigirse por el total contra el sobreviviente o contra cada heredero del fallecido, por una mitad del total de la indemnización: la obligación de pagar ésta es mancomunada para los herederos.

b) La solidaridad, que es lo contrario de la mancomunidad, porque en la pluralidad de deudores de un objeto divisible, cada cual debe pagar el total debido y no una cuota, y en la de acreedores, cada uno puede cobrar el total, es, por ende, especial, en el sentido de deber estar expresamente establecida. El inciso $2^{\circ}$ del artículo 1511 conoce tres fuentes de solidaridad: la convención, el testamento o la ley. El caso de las obligaciones delictuales o cuasidelictuales lo es de solidaridad legal, a tenor de lo dicho por el artículo $2317 \mathrm{CC}$. Como lo muestra este caso y también varios otros, 
la ley puede establecer solidaridad con respecto a obligaciones nacidas de cualquier fuente.

Que la convención sea fuente de solidaridad significa dos cosas. Por un lado, que cuando en cualquier contrato intervenga más de una persona en alguna de sus partes o en ambas, desde el principio pueden éstas pactar la solidaridad de las obligaciones que las afecten. También, por cierto, después pueden convertir en solidarias las obligaciones contractuales originalmente nacidas en forma mancomunada. Por otro, un pacto de solidaridad puede ser establecido para dar carácter solidario a cualquier obligación nacida mancomunadamente de una fuente no contractual, vale decir, de la ley o de un cuasicontrato.

b) También el testamento puede ser fuente de solidaridad. Es lícito al testador, en efecto, imponerla en los siguientes órdenes: i) en el pago de las deudas hereditarias de objeto divisible (artículo 1526 No 4), impidiendo, así, su normal división a prorrata entre todos los herederos (artículo 1354 CC.); ii) en el pago de las deudas testamentarias de objeto divisible, vale decir, de los legados de efecto obligacional sobre tales objetos (artículo 1360 inciso $2^{\circ}$ ). Este último es el caso que nos interesa. Según él, pues, el testador que dispone un legado de efectos obligacionales de algo divisible, si no grava con su pago a un único heredero o legatario, y lo deja a cargo de todos los herederos, aun así puede imponerles solidaridad pasiva, de guisa que el legatario pueda dirigirse contra cualquier de ellos por todo el objeto de su asignación. Por cierto, también podría dejar el pago a cargo de algunos herederos o de algunos legatarios en forma solidaria. Lo dicho para la solidaridad pasiva vale para la activa, si el testador lega un mismo objeto divisible o una misma parte de un tal objeto a varios, el crédito que se forma a favor de todos los legatarios, que es en principio mancomunado, se convierte en activamente solidario si el testador así lo dispone.

\section{Obligaciones divisibles e indivisibles.}

Nos referimos a la divisibilidad o indivisibilidad determinada por el carácter divisible o indivisible de la prestación o de su objeto (artículo 1524 CC.). Esta dualidad es Derecho general, así que puede darse con respecto a cualquier tipo de obligaciones. Distinto es que, atendido el objeto tipificado de ciertas obligaciones, en algunos casos no pueda ser indivisible. Así, las obligaciones emanadas de delito o cuasidelito, que tienen por objeto dar una cantidad de dinero a título de indemnización, son, pues, siempre divisibles. Que la ley las declare solidarias, si son varios los deudores (artículo 2317 CC.), eso no les quita su naturaleza divisible (artículo 1525 CC.). En el resto, no pueden darse reglas generales, y todo dependerá de la divisibilidad del objeto o de la prestación. 
Lo cual es, por ende, válido para las obligaciones emanadas de legados de efecto obligacional, que tanto pueden recaer sobre prestaciones divisibles de dar, o divisibles o indivisibles de hacer o no hacer, y sobre cosas divisibles o indivisibles. Si el testador ordena dar un fundo a un legatario y deja dos herederos (que lo son por iguales partes), éstos, que son los deudores de la obligación emanada del legado, pueden cumplirla por partes, dando solvendi causa (por inscripción de la escritura de pago) cada cual la mitad del dominio que entretanto tiene como heredero al legatario, de modo que éste se haga dueño del total al cumplir por último cualquiera de los dos deudores. Si en cambio, lega obligacionalmente un caballo purasangre, aunque se trata de un dar solvendi causa, en principio divisible, como ahora la dación consiste en una tradición, cuya materialidad no puede cumplirse por partes del animal, la obligación es indivisible, y deberá entregar el animal cualquiera de ambos herederos en el todo indiviso (artículo 1526 No $2^{41}$ ).

\section{Obligaciones con cláusula penal.}

El Código presenta las obligaciones con cláusula penal en el título $11^{\circ}$ de su libro IV como si se tratara de una especial clase de obligación, en circunstancias que, entre vivos, la cláusula penal es una convención accesoria de algún contrato y, por causa de muerte, de una disposición testamentaria ańadida a un legado o a otra asignación. En todo caso, lo que interesa aquí es esto último; es decir, la posibilidad de que el testador imponga cláusula penal para el incumplimiento de un legado suyo dispuesto en forma obligacional. Posibilidad que no hay razones para desechar. El testador puede, por ejemplo, decir: "Lego el fundo Corneliano de mi heredero Ticio a Cayo"; o sea, disponer un legado del tipo previsto por la primera parte del artículo 1107 CC.: "El legado de especie que no es [...] del asignatario a quien se impone la obligación de darla es nulo; a menos que en el testamento aparezca que el testador sabía que la cosa no era [...] del dicho asignatario [...]", que necesariamente produce efecto sólo obligacional (pese a ser sobre especie), como, por lo demás, lo dice expresamente la disposición ("a quien se impone la obligación"). Ahora bien, si el testador añade a este legado la siguiente declaración de voluntad suya: "[...] y si el mencionado heredero no quisiere o no pudiere transferir el fundo al legatario, lego a éste 1.000 a cargo del mismo heredero", en el entendido que la suma señalada es más alta que la del valor del predio. Incluso podría

${ }^{41}$ El caso previsto en esta norma viene presentado como "excepción a la divisibilidad"; pero sin razón, porque la obligación de dos de dar un objeto indivisible es indivisible ella misma, y no se trata de una excepción. 
el testador decir expresamente que se trata de una cláusula penal: "[...]a cargo del mismo heredero a título de pena". Esta segunda disposición es enteramente válida, a tenor de lo dispuesto por el artículo 1069 inciso $1^{\text {a }}$ CC.: "Sobre las reglas dadas en este titulo acerca de inteligencia y efecto de las disposiciones testamentarias, prevalecerá la voluntad del testador claramente manifestada, con tal que no se oponga a los requisitos o prohibiciones legales", pues nada en ella hay, en efecto, que contravenga algún requisito o alguna prohibición legal.

La posibilidad de que el testador establezca cláusulas penales destinadas a asegurar el cumplimiento de sus legados (o de cualquier otra asignación) está fuera de duda, por más que la doctrina la pase bajo silencio.

\section{Conclusión.}

El resultado final de la precedente indagación es que las diversas clasificaciones de las obligaciones son aplicables a las nacidas de legado de efectos personales. Esto no tiene nada de extrańo. En el Código, el tratado sobre los diversos tipos de obligaciones tiene carácter funcional, no estructural; es decir, no depende de una fuente obligacional determinada y se aplica, por ende, a las obligaciones nacidas de cualesquiera de ellas; por ende, también a las nacidas de un legado. El análisis revela, empero, que con frecuencia muchas de las clasificaciones terminan por limitarse a las obligaciones contractuales y de legado. No existen casos en que aquéllas y éstas, o sólo éstas, queden excluidas; así que con propiedad puede decirse que el dicho tratado, pese a su carácter funcional y, por consiguiente, universal, de hecho es por lo ordinario propio de las obligaciones contractuales y de legado.

\section{LA OBLIGACIÓN NACIDA DE LEGADO FRENTE A LAS NORMAS RELATIVAS AL EFECTO DE LAS OBLIGACIONES}

El título $12^{\circ}$ del libro IV CC., rubricado: Del efecto de las obligaciones, atendida ella, debería ser un tratado meramente funcional, aplicable a las obligaciones provenientes de cualquier causa o fuente. Sin embargo, algunas de sus disposiciones singulares fueron redactadas en atención a las obligaciones nacidas de contrato, con lo cual el Código transita al criterio estructural. En esta parte de nuestro trabajo estudiaremos la posibilidad de aplicar las disposiciones estructurales del mencionado título a las obligaciones nacidas de legado de efecto obligacional, o al menos de encontrarles un correlato para ellas.

Con ello ingresamos en un campo prácticamente inexplorado. No es nuestra intención agotarlo, porque el tema excede los límites panorámicos de un trabajo como el presente; por lo cual nos limitaremos a unas 
indicaciones generales, dadas con la esperanza de que sirvan de punto de partida a otros.

Además debemos advertir que el tema, en varios casos, también excede a los legados hasta extenderse a todo el testamento y a sus diferentes especies de asignaciones. Por lo demás, tal es otra razón de ceñirnos a las anunciadas indicaciones generales, atendido que este trabajo atañe sólo a los legados.

\section{Artículo 1545 CC.}

Esta célebre disposición se puede leer compatible y complementariamente de tres maneras. De una resulta la idea de autonomía de la voluntad. De otra, más consonante con su letra, deriva la idea que resumimos bajo la fórmula de la "ley del contrato". De la tercera, también consonante con la letra, se obtiene la idea de la intangibilidad e irrevisabilidad del contrato.

a) La idea emanada de la primera lectura no se hace posible más que en concordancia con el artículo 1445 CC., según el cual si dos personas capaces que consientan sin vicios en obligarse sobre un objeto lícito y con causa lícita (y con obsequio a las solemnidades legales expresamente establecidas ${ }^{42}$ ), se obligan efectivamente sin más. De acuerdo con esto, como nada más exige la ley, si las partes cumplen los dichos requisitos mínimos, pueden celebrar las convenciones que quieran con el contenido que decidan, cuando no están tipificadas en el ordenamiento y también pueden modificar el estatuto de las que lo están, si no tiene carácter imperativo o prohibitivo.

En el Código no existe una disposición así de analítica que paralelamente haya sido redactada con referencia a las disposiciones testamentarias. Pero el artículo 1069 CC., insertado en el $\$ 1$ del título $4^{\circ}$ del libro III, que ofrece un carácter sintético, debe ser mirado como el paralelo en los legados, de la autonomía de la voluntad en los contratos; así que podríamos hablar del principio de la autonomía de la voluntad del testador. Reza la norma: "Sobre las reglas dadas en este titulo acerca de inteligencia y efecto de las disposiciones testamentarias, prevalecerá la voluntad del testador claramente manifestada, con tal que no se oponga a los requisitos o prohibiciones legales".

Cierto es que ella tiene alcances más limitados que en materia de contratos, atendido que el Código no conoce la idea de libertad absoluta de testar más que en determinadas circunstancias del testador. Si éste testa careciendo de ascendientes, descendientes o cónyuge, tiene absoluta libertad

${ }^{42}$ Lo que deriva del artículo 1682 CC., en donde define las nulidades por omisión de "requisitos o formalidades". 
para asignar como quiera todos sus bienes y, entre otras, de distribuirlos todos ellos como legados. Si lo hace teniendo alguno de esos parientes o cónyuge, su libertad absoluta se limita al cuarto de sus bienes, a los que se imputan sus legados, mientras que sobre el otro cuarto tiene libertad relativa para asignar como quiera, pero entre los llamados mejoreros (artículo 1195 CC.); y sobre la mitad carece absolutamente de libertad, pues toda esa parte debe ir necesariamente a los legitimarios (artículo 1184 CC.) ${ }^{43}$.

Por consiguiente, es claro que lo dicho acerca de la autonomía de la voluntad del testador rige en los ámbitos en que hay libertad de testar. Por lo demás, dicha autonomía vale no sólo para los legados, mas también y desde luego para las herencias y otras asignaciones.

b) La idea de que el testamento es una ley, igual que el contrato ${ }^{44}$, no está declarada en ninguna disposición singular; pero que es así resulta del sistema sucesorio adoptado por el Código y de la universalidad de su articulado sobre el testamento y sus disposiciones y asignaciones, que carecerían de todo sentido si no postulamos que el testamento es una ley. Ahora bien, aquel no tiene partes sino un único autor. ¿Para quién es, pues, ley? No, desde luego para su autor, porque el testamento es siempre revocable por él mismo en vida (artículos 999 y 1001 CC.). El acto, en realidad, empieza a surtir efectos con su muerte (artículo 999 CC.: "para que tenga pleno efecto después de sus dias"); mas, como precisamente el autor ya no existe, tampoco es ley para él cuando aquél empieza a operar. Por consiguiente, este carácter se predica con respecto a los asignatarios nombrados en el testamento, a los ejecutores testamentarios y a los partidores. Pero no simple y directamente, mas previa aceptación de la asignación o del nombramiento como ejecutor o partidor.

c) La idea de la intangibilidad e irrevisabilidad del testamento hay que referirla, como es natural, a la época en que este puede empezar a tener efecto, vale decir, a aquella que empieza con la muerte del testador (artículo 999 CC. ya citado). Antes de morir, su autor lo puede revisar (y revocar) cómo y cuántas veces quiera; y no existe recurso alguno a favor de nadie para obligar al testador a revocar o a impedirle revocar, ni a obligarlo a modificar o a impedirle modificar su testamento. En vida, un testador no

${ }^{43}$ Dejamos a un lado la asignación forzosa de alimentos ( $\$ 1$ del título $5^{\circ} \mathrm{del}$ libro III CC.), ya que estos son deudas hereditarias y no propiamente una asignación; acerca de lo cual, véase: GuZmán BRITO, Alejandro, La doble naturaleza de deuda hereditaria y asignación hereditaria forzosa de los alimentos debidos por ley a ciertas personas, en Revista Chilena de Derecho 35 (2008) 2, pp. 311-339.

${ }^{44}$ Los juristas romanos emplean la idea de lex privata no sólo con respecto al contrato (lex contractus), mas también con respecto al testamento (lex testamenti). 
está, pues, ligado a su propio testamento bajo ningún respecto, excepto en algún caso muy excepcional y del todo explicable ${ }^{45}$.

Otra cosa es desde que el testador muera: desde entonces se hace inmodificable como tal bajo ninguna circunstancia, con alguna razonable excepción, como la dispuesta por el artículo 1093 inciso 2o CC.: "Si el modo, sin hecho o culpa del asignatario, es solamente imposible en la forma especial prescrita por el testador, podrá cumplirse en otra análoga que no altere la substancia de la disposición, y que en este concepto sea aprobada por el juez con citación de los interesados". No atentan contra este rasgo del testamento los no pocos casos en que la ley permite a los asignatarios adoptar acuerdos o a los ejecutores testamentarios o al partidor librar resoluciones, concernientes a determinados puntos sucesorios con alguna libertad; porque estos, o atañen a los efectos del testamento y no al testamento mismo, o versan sobre materias no resueltas en el testamento, o discurren sobre la base de afectarse derechos que pueden renunciarse o modificarse. Así, por ejemplo, si el testador distribuyó el pago de las deudas hereditarias o testamentarias de una manera determinada entre sus herederos, y éstos acuerdan distribuirlas de otra manera, estos acuerdos valen (artículos 1359 y 1373 inciso 2o CC.), aunque aparentemente modifican el testamento. Pero en rigor no es así, porque los asignatarios actúan no tanto en tal calidad, cuanto en la de deudores y a este respecto no se diferencian de cualquier grupo de deudores entre vivos, que igualmente podrían adoptar un acuerdo sobre distribución de ciertas deudas comunes distinta a la prevista en el contrato original, sin que por ello se entienda modificado éste. La contraprueba es que tales acuerdos vinculan a quienes los adoptaron, mas a no a los terceros y, en primer lugar, no a los acreedores, los cuales pueden insistir en atenerse al testamento (artículos 1358 y 1373 inciso 2o CC.)

\section{Artículo 1546 CC.}

Esta norma contiene el principio de la ejecución de buena fe de los contratos. En doctrina, no sólo se trata de la ejecución, pues la buena fe rige en todas las etapas del contrato, incluso en aquella precontractual. Ahora bien si nos limitamos al dictado legal, ¡es inaceptable decir que los testamentos, y en especial los legados, deben ejecutarse de buena fe?

La buena fe en materia testamentaria no cabe exigirla, por cierto, al testador sino a quienes quedan regidos por la lex testamenti después de muerto aquél, y, en especial, a los asignatarios y ejecutores; tanto en sus

${ }^{45}$ Como el reconocimiento testamentario de un hijo (artículo 189 inciso $2^{\text {a }}$ CC.). 
relaciones recíprocas como en sus relaciones con terceros interesados, tales cuales, por ejemplo, con los acreedores hereditarios ${ }^{46}$.

\section{Artículo 1547 CC.}

a) En el inciso $1^{\circ}$ de esta disposición se indica el tipo de culpa de que responde el deudor según la parte en la cual recaiga la utilidad o el beneficio del contrato de que deriva su deuda: responde de la culpa lata si aquél es útil sólo para el acreedor; de la leve si es en beneficio recíproco de ambas partes; y de la levísima si sólo beneficia al deudor.

El inciso $2^{\mathrm{a}}$ exonera de responsabilidad al deudor en el evento de un caso fortuito no acaecido durante su mora ni por su culpa. El inciso $3^{\mathrm{a}}$ carga la prueba de la diligencia o cuidado al que ha debido emplearla; $y$ del caso fortuito al que lo alega. El inciso $4^{\mathrm{a}}$ no nos interesa.

Preliminarmente recordemos que el legado, como acto jurídico, no tiene partes; sólo tiene un autor: el testador. Pero aquellos de efecto obligacional dan lugar a un acreedor y a un deudor. Su acreedor es el legatario; y su deudor, en principio todos los herederos a prorrata de sus cuotas hereditarias o en la proporción señalada por el testador; o bien, si éste lo estableció, un heredero determinado o varios de ellos; o, todavía, uno o varios legatarios (artículo 1360 CC.). La aceptación de la herencia o el legado, por la cual el heredero o el legatario, junto con adquirir su asignación, se hace también deudor testamentario, si es el caso, según lo antes dicho, va mirada como un cuasicontrato por el artículo 1437 CC. Podemos, pues, decir que, no obstante no tener partes el acto jurídico llamado legado, la relación jurídica legataria o, si se prefiere, el cuasicontrato que se forma con la aceptación, sí las tiene.

b) Ahora bien, ¿cuál es la extensión de la responsabilidad del deudor de una especie legada obligacionalmente? ${ }^{47}$

En el Código, la norma aparentemente más cercana al tema de que hablamos está en su artículo 1118: "La especie legada se debe en el estado en que se encuentra al tiempo de la muerte del testador [...]". Pero ella, como se ve, no trata de la culpa. Su tema, en realidad, es otro que el del grado de responsabilidad que afecta al deudor. Por un lado aclara que las modificaciones, aun culpables, sufridas por la cosa antes de morir el testador, no se toman en cuenta en lo tocante a alguna eventual respon-

${ }^{46}$ Véase Zannoni, Eduardo, La buena fe en el derecho sucesorio, en CóRdoba M. (director), Tratado de la buena fe en el Derecho (Buenos Aires, La Ley, 2004), I, pp. 633-637, no limitado al testamento sino, como lo indica el título, extendido a todo el Derecho de sucesiones.

${ }^{47}$ Que sepamos, este punto, que en final de cuentas se plantea así: ¿¿de qué culpa responde el deudor de lo legado? no ha sido tratado por la doctrina. 
sabilidad ante el legatario. Por otro, fija el momento en el cual empieza dicha responsabilidad.

c) La norma que sí recibe aplicación al caso de obligaciones de especie derivadas de legado, cuando se deteriora, es la del artículo 1590 CC.: "Si la deuda es de un cuerpo cierto, debe el acreedor recibirlo en el estado en que se halle; a menos que se haya deteriorado y que los deterioros provengan del hecho o culpa del deudor, o de las personas por quienes éste es responsable; o a menos que los deterioros hayan sobrevenido después que el deudor se ha constituido en mora, y no provengan de un caso fortuito a que la cosa hubiese estado igualmente expuesta en poder del acreedor. [inciso $2^{\circ}$ ] En cualquiera de estas dos suposiciones se puede pedir por el acreedor la rescisión del contrato y la indemnización de perjuicios; pero si el acreedor prefiere llevarse la especie, o si el deterioro no pareciere de importancia, se concederá solamente la indemnización de perjuicios. [inciso 30] Si el deterioro ha sobrevenido antes de constituirse el deudor en mora, pero no por hecho o culpa suya, sino de otra persona por quien no es responsable, es válido el pago de la cosa en el estado en que se encuentre; pero el acreedor podrá exigir que se le ceda la acción que tenga su deudor contra el tercero, autor del daño".

La primera parte del inciso $1^{\circ}$ dice lo mismo que el artículo 1118 CC., sólo que ésta aparece redactada desde el punto del deudor ("La especie legada se debe [...]"); mientras que la dicha primera parte está redactada desde el punto de vista del acreedor ("debe el acreedor recibirlo"). Claro es que, empero, esta última norma no dice ella cuál es el momento decisivo, que el artículo 1118 CC., en cambio, expresa: "al tiempo de la muerte del testador". Los segmentos que siguen del inciso $1^{\circ}$ de este último artículo, en cambio, se echan de menos en el artículo 1118 CC., y por ello son aplicables a las deudas de especie emanadas de un legado obligacional. En síntesis, se dice en el resto del inciso $1^{\circ}$ que el acreedor puede rehusar recibir la cosa deteriorada: i) por hecho o culpa del deudor del legado (un heredero o un legatario), o de las personas por las cuales responde; lo cual significa culpa o dolo del deudor; ii) por caso fortuito durante la mora del deudor, si tal caso no fue de aquellos a que resultaría igualmente expuesta la cosa de haber estado en poder del acreedor.

El inciso $2^{a}$ concede esta alternativa al acreedor: i) pedir la resolución (que es el significado que ahí asume la palabra "rescisión") del "contrato" y la indemnización de perjuicios, si el deterioro pareciere de importancia; ii) o, si lo prefiere, o si el deterioro no pareciere de importancia, recibir la especie existente pero deteriorada y pedir la dicha indemnización. Cabe preguntarse si lo que la norma dice del "contrato" es aplicable al legado; vale decir, si cabe la posibilidad de resolver éste, en las condiciones señaladas en ella. Y, en verdad, no vemos motivos para negarlo. 
El inciso $3^{\circ}$ se sitúa en el caso en que el deterioro haya sobrevenido antes de constituirse el deudor en mora, pero no por hecho o culpa suya, sino de otra persona por quien no es responsable: en tal evento, el deudor paga válidamente la especie existente en el estado en que se encuentre; pero el acreedor puede exigir que se le ceda la acción que su deudor contra el tercero autor del daño".

c) Cuando, en cambio, la especie legada debida perece, se hace aplicable el artículo 1672 CC.: "Si el cuerpo cierto perece por culpa o durante la mora del deudor, la obligación del deudor subsiste, pero varía de objeto; el deudor es obligado al precio de la cosa y a indemnizar al acreedor. [inciso 20] Sin embargo, si el deudor está en mora y el cuerpo cierto que se debe perece por caso fortuito que habria sobrevenido igualmente a dicho cuerpo en poder del acreedor, sólo se deberá la indemnización de los perjuicios de la mora. Pero si el caso fortuito pudo no haber sucedido igualmente en poder del acreedor, se debe el precio de la cosa y los perjuicios de la mora".

El deudor del legado responde si la cosa se haya perdido: i) por culpa o dolo del deudor (o sea, de un heredero o un legatario); ii) durante la mora del deudor, por hecho suyo sin culpa o dolo (que no sea del previsto por el artículo 1678 CC.) o por hecho de terceros; y en tales casos su responsabilidad comprende el precio de la cosa y la indemnización de perjuicios al acreedor; vale decir, el daño emergente y el lucro cesante compensatorio y moratorio (artículo 1672 inciso $1^{\circ}$ ). Si la cosa se haya perdido iii) durante la mora del deudor por caso fortuito, que no hubiera sobrevenido igualmente a dicho cuerpo en poder del acreedor, su responsabilidad comprende el precio de la cosa y la indemnización de los perjuicios de la mora. Si el caso fortuito sobrevenido hubiera podido acaecer igualmente estando la cosa en poder del acreedor, la responsabilidad se limita a la indemnización de los perjuicios de la mora (artículo 1672 inciso $2^{\circ}$ ).

$\mathrm{Si}$, finalmente, la cosa debida pereció por un hecho voluntario del deudor que inculpablemente ignoraba la obligación, en cualquier tiempo antes del pago, este responde del precio de la cosa sin otra indemnización, añade el artículo 1678 CC.

d) Pero el Código no ha dicho de qué culpa responde el deudor de lo legado. El inciso $1^{\circ}$ del artículo 1547 no sería aplicable porque ahí se habla del grado de culpa de cada parte de un contrato; y el legado, junto con no tener partes, no es un contrato. Ahora bien, como la ley no especifica el tipo de culpa que afecta al deudor de la especie legada, aunque lo hace responder por culpa, debemos concluir que esta es la culpa lata, por ser la mínima posible. Por lo demás, este criterio hace sistema con el dispositivo del artículo 1547 inciso $1^{\circ}$ sobre contratos: en ellos, de la culpa lata responde el deudor cuando el contrato es sólo útil al acreedor. 
Ahora bien, la relación legataria, o el cuasicontrato, es sólo útil al acreedor, es decir, al legatario.

\section{Artículos 1548 y 1549 CC.}

La primera norma señala que la obligación de dar una cosa contiene la de entregarla, que si es una especie, contiene, además, la de conservarla hasta la entrega, so pena de pagar los perjuicios al acreedor no moroso en recibir. La segunda indica que la obligación de conservar una cosa exige que se emplee en su custodia el debido cuidado.

No parece discutible que ambas disposiciones se aplican a la obligación de dar una especie emanada de un legado de tal, con efecto personal $\mathrm{u}$ obligacional. Si el testador dijo: "Que mi heredero Ticio dé a Cayo mi purasangre 'Centella", he ahí que el heredero habrá de quedar obligado a dar la especie designada al legatario; pero también a entregársela y a conservarla hasta la entrega y, finalmente, a emplear entretanto el debido cuidado en su custodia; debido cuidado que, como vimos en el número anterior, es el mínimo para no incurrir en culpa lata.

\section{Artículo 1550 CC.}

La norma contiene la doctrina sobre el riesgo por la pérdida del cuerpo cierto debido, esto es, sobre quién deba sufrirla cuando acontezca un perecimiento fortuito del cuerpo cierto debido. La doctrina dice que ese riesgo es siempre para el acreedor si el deudor no se ha constituido en mora; y para el deudor en caso contrario. Aplicada ella a la obligación de dar o entregar un cuerpo cierto, emanada de cierto legado capaz de generarla, resulta que el riesgo del cuerpo cierto así legado es para el legatario, si el heredero (o legatario) no ha caído en mora: o para uno u otro en el caso contrario. Lo cual concuerda con lo antes dicho, en orden a que el caso fortuito exonera al heredero (o legatario) deudor del legado no constituido en mora.

\section{Artículo 1551 CC.}

Esta norma expone la doctrina de la mora del deudor. No cabe duda que ella es aplicable al que debe cumplir un legado asignado en forma obligacional. Pero el punto es cómo se constituye en mora a ese deudor. La doctrina común, sobre bases jurisprudenciales, sostiene que bajo la forma señalada por el No 3: "El deudor está en mora: "[...] 30 En los demás casos, cuando el deudor ha sido judicialmente reconvenido por el acreedor", vale decir, por el legatario. La razón es que, no bien el legado pueda contener un plazo de cumplimiento fijado por el testador, aun así no se hace aplicable el No 1: "El deudor está en mora: 10 Cuando no ha cumplido la obligación dentro del término estipulado [...]" porque un término testamentario no es 
"estipulado" sino impuesto unilateralmente por el testador ${ }^{48}$. De donde que la mora del deudor testamentario deba ser operada de acuerdo con el No 3 del artículo en examen, como se dijo.

\section{Artículo 1553 CC.}

La norma expone el régimen a que se somete el deudor de hacer moroso. El acreedor puede pedir, además de la indemnización de la mora, alguna de estas tres cosas a su elección: i) el apremio al deudor para que ejecute el hecho debido; ii) una autorización para ejecutarlo el acreedor a expensas del deudor; iii) la indemnización por el deudor, de los perjuicios resultantes de la infracción del "contrato". Puesto que un legado dispuesto bajo forma obligacional puede tener por contenido una prestación de hacer $^{49}$, la norma es perfectamente aplicable a tal tipo de obligaciones. La leve dificultad, consistente en que el No 3 del artículo 1553 hable de "infracción del contrato", cuando en realidad se trataría de infracción del "legado" (o del "testamento") debe ser fácil y razonablemente superada merced a la analogía.

\section{Artículo 1555 CC.}

Este artículo trata de la disciplina de la responsabilidad por el incumplimiento de las obligaciones de no hacer. Ellas se resuelven -dice la norma- en la de indemnizar los perjuicios si el deudor contraviene la obligación y no puede deshacerse lo hecho. Si la contravención consistió en construir una cosa que no debía ser construida y puede destruírsela cuando su destrucción es necesaria para el objeto que se tuvo en vista al tiempo de "celebrarse el contrato", se puede obligar al deudor a destruir o autorizar al acreedor para que destruya él a expensas del deudor. Cuando, en cambio, el objeto tenido en mira puede obtenerse cumplidamente por

${ }^{48}$ Véase: Abeliuk Manasevich, Las obligaciones, cit. (n. 6), I, núm. 873, pp. 716-717; Domínguez Benavente, R. - Domínguez Águila, R., Derecho sucesorio, cit. (n. 24), II, núm. 837, pp. 826-827. Es efectivo que el Código original siempre usa el verbo "estipular" en un sentido convencional, como "convenir, acordar, contratar”, etcétera; y por ello el razonamiento expuesto, en orden a que el № 1 del artículo 1551 CC. solo atañe a los términos convencionales es correcto. Sin embargo, esta reserva exclusiva del uso de "estipular" para lo convencional ha dejado de existir desde que la Ley No 19.585 (DO. de 26 oct. 1998) creó el siguiente nuevo artículo 250 CC.: "La patria potestad confiere el derecho legal de goce sobre todos los bienes del hijo, exceptuados los siguientes: [...] 2. Los bienes adquiridos por el hijo a título de donación, herencia o legado, cuando el donante o testador ha estipulado que no tenga el goce o la administración quien ejerza la patria potestad [...]". Como se ve, la norma también predica de un testador con el verbo "estipular".

${ }^{49}$ Véase, más arriba, cap. VIII, 1. 
otros medios, será oído el deudor que se allane a prestar dicho objeto. En todos los casos, el acreedor debe quedar indemne.

Este régimen es del todo aplicable a las deudas testamentarias emanadas de un legado de efecto obligacional, cuya prestación consista en un no hacer. Cabe repetir lo dicho en el número anterior con respecto, ahora, a la expresión "al tiempo de celebrarse el contrato" usada aquí, que debe ser leída como si dijera "al tiempo de otorgarse el testamento", cuando se traslade la norma a los legados ${ }^{50}$.

\section{Artículos 1556 y 1557 CC.}

En el artículo 1556 CC. va descrita la consistencia de la indemnización de perjuicios, que comprende el daño emergente y el lucro cesante, por el incumplimiento absoluto o bien imperfecto de la obligación, o por el retardo en su cumplimiento. Por su parte, el artículo 1557 CC. declara que la indemnización se debe desde la mora del deudor o desde la contravención cuando la obligación es de no hacer.

No cabe duda que ambas disposiciones son completamente aplicables a las obligaciones emanadas de un legado.

\section{Artículo 1558 CC.}

En su inciso $1^{\circ}$, el precepto define la extensión de los perjuicios indemnizables, según el tipo de imputación que pueda hacerse al deudor. Si obró con dolo, responde de todos los perjuicios que fueron una consecuencia inmediata o directa del incumplimiento o de la mora en el cumplimiento de la obligación. Si actuó sin dolo, únicamente responde de los perjuicios que se previeron o pudieron preverse "al tiempo del contrato". Cuando la norma supone que no haya habido dolo, lo que dice es que haya habido culpa; porque en su inciso $2^{\mathrm{a}}$ añade que la mora producida por fuerza mayor o caso fortuito no da lugar a indemnización de perjuicios.

El precepto es aplicable en ambos incisos a las deudas emanadas de un legado de efecto obligacional, cuyo sujeto obligado, sea un heredero o varios, o un legatario o varios, pudieron incumplir o demorarse en cumplir con dolo o culpa. Nuevamente es preciso superar la restricción literal en el inciso $1^{\circ}$, que habla de "preverse al tiempo del contrato", y entenderse como si dijera "preverse al tiempo del cuasicontrato", vale decir, de la aceptación del legado, como es, por lo demás, del todo lógico.

${ }^{50} \mathrm{El}$ punto de referencia no es, pues, "el tiempo de morir el testador" ni aquel de "aceptarse el legado". Se trata del "objeto que se tuvo en mira"; y el único que pudo tener algo en mira fue el testador; y solamente en el momento de testar. 


\section{Artículo 1559 CC.}

Este artículo contiene prescripciones aplicables a la indemnización de perjuicios por la mora en el cumplimiento de las deudas de dar dinero. Su aplicabilidad a los legados de dinero, siempre obligacionales, está fuera de discusión. Sólo cabe observar que el No 1 , que ordena seguir debiéndose los intereses convencionales, si se ha pactado un interés superior al legal, o que empiezan a deberse éstos en el caso contrario, sólo es aplicable a los legados de dinero en este último caso, pues, como es natural, en ellos no pueden haber originariamente intereses convencionales; así que sólo procede el cobro de los legales. Cabe, empero, preguntarse si el testador puede imponer el pago de intereses superiores al legal para el caso de mora en pagarse el legado; y no vemos razones que impidan dar una respuesta positiva, sobre todo a tenor de lo establecido por el artículo 1069 inciso $1^{\circ} \mathrm{CC}$.

\section{Conclusión.}

De esta manera, pues, debemos concluir que los diversos artículos componentes del título $12^{\circ}$ del libro IV CC. son aplicables a las deudas emanadas de un legado de efecto obligacional. Sólo se excluyen aquellos que claramente y sin posibilidad ni necesidad de intentar analogía sobre su base, se aplican a las obligaciones contractuales, como el artículo 1552 CC., sobre condición resolutoria tácita, que por su naturaleza sólo puede operar en los contratos bilaterales; o el artículo 1554 CC. que -mal localizado en el título- tipifica un contrato específico, como es el de promesa de contrato, que tampoco es aplicable a los legados, aunque quepa discutir si un testador pueda obligar por legado a un heredero suyo a celebrar cierto contrato con un tercero (cfr. un caso en el artículo 1106 CC.).

Esta general aplicabilidad del título en examen a las obligaciones legatarias tampoco debe extrañar. Ese título está presidido por una concepción funcional y no estructural, de modo de ser adaptable a las obligaciones nacidas de cualquier fuente (aunque a veces se le hayan escapado algunas referencias al contrato). Que no siempre se tenga ello en cuenta, eso es otro asunto.

\section{ALGUNOS MODOS DE EXTINGUIR OBLIGACIONES QUE PUEDEN SER OPERADOS INDISTINTAMENTE ENTRE VIVOS O POR LEGADO}

En este capítulo trataremos de ciertos modos de extinguir obligaciones que funcionalmente pueden tener lugar indistintamente entre vivos o por medio de un legado. No se trata de examinar aquí, en cambio, cómo las obligaciones nacidas de legado pueden acabarse merced a los distintos modos de extinguir obligaciones, porque ello es evidente que puede acaecer. 
El régimen extintivo de obligaciones es común a las nacidas entre vivos, incluso cuando se convierten en créditos o en deudas hereditarios debido a la muerte del acreedor o del deudor, y a las nacidas de legado; así que nada especial hay que decir al respecto. Pero es interesante verificar que algunos efectos extintivos de obligaciones preexistentes, nacidas de cualquier fuente, pueden ser conseguidos, ora por un acto entre vivos, ora por medio de un legado, no bien que en el título $14^{\circ}$ del libro IV CC., destinado a los modos de extinguirse las obligaciones, normalmente suponga tratarse de efectos exclusivamente entre vivos.

Esta posibilidad dual se da en los siguientes modos: pago, remisión, compensación y confusión. Queremos, pues, decir, que el pago, habitualmente pensado como un acto o un efecto entre vivos, también puede tener lugar por causa de muerte merced a un legado; y lo que acabamos de decir para el pago, vale para los demás modos extintivos antes enumerados.

\section{Pago mediante legado.}

a) En el Código Civil, la palabra "pago" es muy ambigua.

Desde luego ella designa el acto jurídico de pagar; pero también el efecto derivado de tal acto, que podemos denominar efecto solutorio. Muchas de las disposiciones de los $\$ \$ 1$ a 10 del título $1^{\circ}$ del libro IV CC. y de las demás concernientes esparcida a lo largo del Código pueden ser leídas con ambos significados, porque, supuesto el acto, se supone seguido el efecto; pero varias directamente sólo se leen en su significado de acto. Así, por ejemplo, el artículo 1569 CC.: "El pago se hará bajo todos respectos en conformidad al tenor de la obligación; sin perjuicio de lo que en casos especiales dispongan las leyes./ [inciso 20] El acreedor no podrá ser obligado a recibir otra cosa que lo que se le deba ni aun a pretexto de ser de igual o mayor valor la ofrecida". En el inciso $1^{\circ}$, se trata de "hacer" el pago, vale decir, de ejecutar un acto; en el inciso $2^{\circ}$, de lo que puede ser obligado a "recibir" el acreedor, y nuevamente se mienta el acto (o parte del acto) de pagar. Por cierto, el efecto solutorio sólo se seguirá si se cumplen las exigencias de ambos incisos; pero tal efecto no es el tema de la disposición.

Por otra parte, según la definición del artículo 1568 CC., el pago es "la prestación de lo que se debe"; y tal definición vale para el cumplimiento de cualquier tipo de obligación, sea de dar, de hacer o de no hacer. Pero tan amplio sentido conferido al término no puede ocultar la diferencia entre el pago de las obligaciones de dar y el de las de hacer y no hacer. De donde que resulte necesario distinguir dos especies en el género "pago" entendido como "la prestación de lo que se debe". El propio Código establece la distinción cuando en su artículo 1575 individualiza un "pago que debe transferir la propiedad", lo cual permite separarlo de un pago "que no debe 
transferir la propiedad", como acaece en el de las obligaciones de hacer y no hacer, y especialmente en las de meramente entregar. He aquí, pues, la segunda ambigüedad del único término empleado para designar los dos tipos de pago dichos. La cual, por cierto, se combina con la primera, pues el vocablo "pago" aplicado a aquel que transfiere la propiedad y aquel que no la transfiere puede ser entendido como acto y como efecto, a su vez.

Ahora bien, el pago como acto jurídico y como efecto que es habitualmente pensado o supuesto en los $\$ \$ 1$ a 10 del título $14^{\circ}$ del libro IV CC. es aquel entre vivos, que, cuando se refiere a obligaciones de dar, podemos definir como una convención meramente consensual entre el deudor o un tercero y el acreedor, en orden a dar y recibir una cosa debida a éste, seguida de su tradición. Este acto produce el efecto de extinguir la obligación pagada y satisfacer al acreedor. Pero cumple estudiar la posibilidad de que el pago como efecto solutorio atributivo de la propiedad pueda ser producido por causa de muerte merced a un legado; lo cual implica que también por la intervención de un acto jurídico, solo que de especie diferente, por cierto, a la de aquella convención entre vivos. Al respecto, pues, podríamos hablar de legado en función de pago de obligaciones; las cuales pueden consistir en deudas del testador o de terceros que el testador paga por ellos.

b) Si alguien debe una especie o cuerpo cierto, y en su testamento lega con efecto real esa misma cosa, que sea suya, al acreedor, para pagarle la deuda, como aquélla empieza a pertenecer al legatario desde el día de la delación de lo asignado, supuesta la aceptación, desde ese día se extinguen la deuda original y su acción, y se libera el sucesor que de otro modo hubiera quedado obligado de acuerdo con las reglas generales sobre transmisión de las deudas. El esquema de esta asignación es, pues: "Para pagárselo, lego a Ticio mi fundo Corneliano, que le debo (por tal causa)".

La figura se identifica con el llamado "legatum debiti" en la tradición, no romana sino romanística. La expresión suele traducirse como "legado de deuda", pero mejor se traduce como "legado de lo debido", porque no es que se legue, en efecto, la deuda misma, que produciría confusión de las calidades de deudor y acreedor en éste, y la extinguiría por confusión (artículo 1665 CC.), sino precisamente el objeto de la deuda, o de la obligación mirada pasivamente, que no provoca confusión, aunque sí extinción por vía satisfactoria y solutoria.

Ese legado debe cumplir con varias condiciones.

c) Tiene que ser, en primer lugar, para pagar deudas de especie, no de géneros, lo cual implica que el mismo legado sea de especie, porque el legado con que quisiera pagarse una deuda de género tendría que ser sobre el género de que se trate y un legado de género por su naturaleza 
produce siempre efectos obligacionales y nunca reales; de modo de no ser, pues, pago, sino orden de pagar. Así que esta asignación: "Lego a Ticio los 1.000 que le debo, para pagárselos", aunque posible y válida, y además subsumible en la categoría general del "legatum debiti", no produce ella el efecto solutorio, que sólo tendrá lugar cuando el gravado con el legado, en su cumplimiento, pague por acto entre vivos al acreedor.

Además, el legado debe ser de cosa propia del testador; porque si la especie legada, aunque fuera para pagarla, es ajena, el legado, o es nulo, si el testador no sabía que era ajena (primera parte del artículo 1107 CC.); o vale, si lo sabía, pero se convierte por ministerio de la ley en un legado obligacional de adquirir la especie para darla al asignatario, o de darle en dinero el justo valor de aquélla, cuando su dueño rehusare enajenarla o pidiere un precio excesivo por ella (segunda parte del artículo $1107 \mathrm{y}$ artículo 1106 CC.). En este último caso, como se ve, el pago de la deuda advendrá, no merced al legado, sino merced al acto-pago entre vivos que el gravado con el cumplimiento del legado convertido haga al acreedor.

Enseguida, el legado debe ser de efecto real, vale decir, tiene que haber sido formulado en términos que confieran directamente la propiedad de la especie legada a su asignatario. Si fue formulado en términos obligacionales, por ejemplo así: "Que mi heredero dé el fundo Corneliano a Ticio, que le debo, para así pagarle la deuda", nuevamente acaecerá que el legado aunque, en términos generales es para pagar, no paga él directamente, porque ha de ser el gravado con el cumplimiento de la asignación, vale decir, el heredero en el ejemplo, el que haya de transferir solvendi causa entre vivos el objeto al acreedor, y sólo entonces se habrá producido el pago.

d) La figura de que tratamos puede ser construida a partir del artículo 1131 CC.: "Lo que se lega a un acreedor no se entenderá que es a cuenta de su crédito, si no se expresa, o si por las circunstancias no apareciere claramente que la intención del testador es pagar la deuda con el legado/ [inciso 2] Si asi se expresare o apareciere, se deberá reconocer la deuda en los términos que lo haya hecho el testador, o en que se justifique haberse contraido la obligación; y el acreedor podrá a su arbitrio exigir el pago en los términos a que estaba obligado el deudor o en los términos que expresa el testamento".

Aunque esta norma no se refiere específicamente al "legatum debiti" de especie propia con efecto real, lo incluye en la generalidad de sus términos.

Ella exige que el testador-deudor declare expresamente que lega "a cuenta del crédito", amplia fórmula ésta que nosotros hemos convertido en la idea de legar "para pagar", y que, por cierto, admite cualquier forma de expresión apta a ese fin. La norma también acepta una suerte de manifestación tácita de ese fin, a través de circunstancias de las cuales 
aparezca claramente la intención del testador en orden a pagar la deuda con el legado.

Supuesto, pues, que el legado haya sido expresa o tácitamente formulado para pagar, la ley concede una alternativa de reconocimiento de la deuda al acreedor-legatario $\mathrm{F}^{51} \mathrm{~F}$ : bien en los términos en que la haya declarado el testador a través de su legado, bien en aquellos en que el acreedor justifique haberse contraído la obligación según la causa o fuente original por su deudor; de guisa que el acreedor pueda a su arbitrio exigir el pago en los términos a que le estaba originalmente obligado el deudor o en los términos que expresa el testamento. Porque puede acaecer que el testador haya modificado los términos originales, por ejemplo en cuanto al plazo, si concedió alguno mayor o menor que el original para pagar la deuda con el legado; o en cuanto a ańadir condición suspensiva a éste, que antes no existía, o a haber eliminado o cambiado la condición que antes sí existía; o con respecto al lugar del pago, si cambió el inicialmente fijado, etcétera. Estas variaciones, sobre todo cuando son desfavorables al acreedor, no lo pueden vincular contra su voluntad; de donde la dicha alternativa que le otorga la ley. Pero como hablamos de un legado de efecto real, necesariamente la aceptación del legado implica elección de los términos establecidos en él, porque es incompatible aceptarlo y adquirir el objeto asignado con aceptarlo, adquirir dicho objeto y mantener el crédito original sobre el mismo, escogiendo sus términos originales, que implica abrir el camino a una doble satisfacción. La específica libertad de escoger los términos, que el artículo 1131 CC. acuerda al acreedor queda suficientemente garantizada a través de la más general libertad de aceptar o repudiar el legado.

Si el testador no manifestó voluntad expresa en orden a pagar con su legado ni hay voluntad tácita en esa dirección, como, por ejemplo, cuando el testador que debía el fundo Corneliano a Ticio, se lo lega sin más, esto es, sin manifestar expresa ni tácitamente que se lo lega para pagarle la deuda, desde luego la asignación no vale como legado "de lo debido", pero sí genera un "concurso de causas", cuyos efectos son estos: i) cuando la causa original de la deuda de la especie era gratuita, por ejemplo, si derivó de una obligación donataria, con el legado de esta misma especie al acreedor, la obligación se extingue y deja de gravar, por ende, a los herederos; ii) si la causa original, en cambio, era onerosa, como una venta o permuta, subsiste pese al legado de la especie al acreedor, y los herederos deberán pagarle su

${ }^{51}$ En esta norma hay un punto oscuro, del que tratamos en GuzMÁn Brito, A., La tipología de los legados, cit. (n. 9), p. 83 nota 88 y en el que no insistiremos aquí. 
valor (y no darle la especie, por cierto, porque ya es suya merced al legado). De esto hemos tratado en otro lugar y a él nos remitimos $\mathrm{F}^{52} \mathrm{~F}$.

e) Como los alimentos que un testador estaba obligado a dar en vida por sentencia judicial o transacción son deudas suyas y al morir de todos modos adquieren la calidad de deuda hereditaria transmisible a sus herederos, síguese de ello que, si los lega al alimentario, tal asignación viene a ser un caso especial del legado previsto en general por el artículo 1131 CC., antes examinado; y es, en otros términos, un legado de lo debido al acreedor (el alimentario). Lo propio hay que decir con respecto a aquellos alimentos de cuyo pago el alimentante hubiera en mora de pagarlos al morir, cuyo pago ordena en un legado $\mathrm{F}^{53} \mathrm{~F}$.

f) Hasta aquí hemos tratado del legado para pagar deudas propias del testador. Ahora bien, mediante legado también se pueden pagar deudas ajenas o de terceros.

Dada cierta obligación de especie entre dos terceros, uno acreedor y deudor el otro, algún testador puede legar realmente la especie suya, pero debida por otro al acreedor, para pagarle con ella la obligación del tercero deudor. Tal es, en sí mismo, un ordinario legado de especie propia, pero en función liberatoria. Si el acreedor-legatario acepta la asignación, adquiere el dominio de la especie; pero tal adquisición, por estar destinada a funcionar como pago, extingue la deuda y libera a su deudor.

El legado de que tratamos también exige que el testador manifieste expresa o tácitamente la función de pago que atribuye a su asignación (arg. ex artículo 1131 CC.); en caso de silencio, debe mirarse como un normal legado de especie, sin efecto liberatorio, por ende. Por otro lado, la especie legada debe pertenecer al testador, pues en otro caso, o es nulo el legado (artículo 1107 CC.) o vale, pero con efectos obligacionales, igual que en el caso tratado en el párrafo segundo de la precedente letra c) $\mathrm{F}^{54} \mathrm{~F}$.

\section{Remisión de deudas mediante legado.}

a) De la remisión como modo de extinguir obligaciones, el Código

${ }^{52}$ Ibíd., pp. 82-83.

${ }^{53}$ Sobre esta materia, véase: GuZmán Brito, Alejandro, La doble naturaleza, cit. (n. 43), pp. 311-339.

${ }^{54}$ Puede objetarse que, siendo de especie la deuda del tercero, no puede ser que un tercero, el testador, sea su dueño, en modo de legarla al acreedor. La cuestión es de hecho, pero no impide la construcción jurídica: el deudor puede deber dar una especie que no sea suya al momento de empezar a deberla, con tal que sea suya al pagarla, habiendo esperado, pues, adquirirla en el tiempo intermedio. Si quien en dicho tiempo es el dueño, la lega al acreedor para pagarla, se tiene el caso de nuestro legado. 
trata en el título $16^{\circ}$ de su libro IV. A tenor de lo señalado por el artículo 1653 de ese título, su referencia es a la remisión entre vivos, o sea, al acto inicial o subsiguientemente convencional entre un acreedor y su deudor en orden a extinguir la deuda sin satisfacción; y al efecto derivado de tal acto $^{55}$; porque aquella disposición ordena que la remisión procedente de mera liberalidad quede sujeta a las reglas de la "donación entre vivos". Además, la remisión tácita de que trata el artículo 1655 CC. no puede tener lugar sino que entre vivos, vale decir, en vida del acreedor y por él; y carece de sentido afirmar que mediante un acto por causa de muerte, como cierto legado, el acreedor "entrega voluntariamente al deudor el titulo de la obligación, o lo destruye o cancela". Lo que sí puede es ordenar que un heredero suyo, por ejemplo, ejecute alguno de esos actos; pero ellos siguen siendo entre vivos; solo que ejecutados, no por el acreedor original, sino por su heredero, lo cual no les sustrae aquel carácter.

b) Ahora bien, el efecto que debemos llamar remisorio de deudas también puede, sin embargo, ser producido mediante un legado, que denominamos precisamente de remisión o condonación.

Este legado consiste en la simple y directa condonación, liberación o remisión que el testador pronuncia sobre la obligación de cierto deudor suyo. Si se emplean fórmulas del tipo: "Condono (remito, perdono, libero, etcétera) tal deuda a Ticio (o lo que Ticio me debe)", o semejantes, el legado produce efectos ipso iure retroactivamente al día de la delación, supuesta su aceptación por el legatario; vale decir, la deuda se extingue entonces y se libera el deudor-legatario, sin que los ahora acreedores, vale decir, los herederos del acreedor original resulten satisfechos, como es propio en toda remisión. Tal legado es, por consiguiente, la versión por causa de muerte de la remisión de deudas entre vivos, tratada en el título $16^{\circ}$ del libro IV del Código.

Éste no regula directamente el legado descrito. Lo da por supuesto cuando trata de su revocación, en el artículo 1129: "Si el testador condona en el testamento una deuda, y después demanda judicialmente al deudor, o acepta el pago que se le ofrece, no podrá el deudor aprovecharse de la condonación; pero si pagó sin noticia o consentimiento del testador, podrá el legatario reclamar lo pagado". También lo da por supuesto en el artículo 1130 CC., para determinar su extensión: "Si se condona a una persona lo que debe, sin determinar suma, no se comprenderán en la condonación sino las deudas existentes a la fecha del testamento".

${ }^{55}$ Sobre esta remisión: GUZMÁn Brito, Alejandro, La remisión de deudas en el Derecho civil, en Revista de Derecho de la Universidad Católica de Valparaíso 13 (Valparaíso, 1989-1990), pp. 51-104; después en El Mismo, Estudios dogmáticos de Derecho civil (Valparaíso, Ediciones Universitarias de Valparaíso, 2005), pp. 121-156. 
c) Todo acreedor puede legar el título de su crédito; y tal asignación es entendida por la ley como legado del crédito mismo (artículo 1127 inciso $2^{\circ}$ CC.). Ahora bien, puede acaecer que un acreedor legue el título de un crédito suyo al deudor del mismo. Tal vez haya la tentación de ver en la figura el paralelo por causa de muerte de la operación entre vivos descrita por el artículo 1654 CC. como "entrega voluntaria del título de la obligación al deudor por el acreedor”, que actúa como remisión tácita de la deuda. El testador que lega el título de una obligación ciertamente no lo entrega; pero hace dueño de él a su asignatario que empieza a ser acreedor él mismo; así que podría pensarse en que al legarse el título de la obligación al deudor de ésta, eso es una remisión testamentaria paralela a la entrega entre vivos del mismo título por el acreedor al deudor, que igualmente produciría remisión. Pero no es así. El acto en examen, como se adelantó, es un legado del crédito (artículo 1127 CC.); y cuando se lega el crédito a su deudor, aunque la deuda ciertamente se extingue, el modo operante de tal efecto es la confusión y no la remisión, como insistiremos después $^{56}$.

3. Compensación con ocasión de un legado.

1. El tratamiento que el título $1^{\circ}$ del libro IV CC. hace de la compensación es estrictamente funcional y no estructural. Lo cual se entiende bien porque la compensación es, en sí misma, un puro efecto y no un acto, ya que opera por el sólo ministerio de la ley (primera parte del artículo 1656 CC.). Que así opere, ya excluye su proveniencia de algún acto. Por consiguiente, las obligaciones compensables, si cumplen los requisitos de ser de género, líquidas y actualmente exigibles (artículo 1656 CC.), pueden provenir cada una de cualesquiera y desde luego de distintas fuentes. Bien se puede, en efecto, compensar una deuda generada por cierto delito con otra generada por algún mutuo, etcétera. De donde que la fuente de alguna de las obligaciones compensables, o de ambas también, puede ser un legado de efectos obligacionales. Esto no ofrece especialidad digna de mención alguna.

Con todo, en la prestación de causa para que tenga lugar la compensación legal o efecto compensatorio puede haber un momento voluntario: la asunción, normalmente contractual, por el acreedor de una deuda para con su acreedor, que, de cumplirse los requisitos legales, provoca compensación. Esta sigue operando por el sólo ministerio de la ley y no depende de la voluntad de las partes en su operación; pero sí tuvo su presupuesto en el acto de haberse deliberadamente creado la segunda obligación. Entre

${ }^{56}$ Véase, más abajo, el número 4 del presente capítulo. 
vivos, salvo en el caso de obligaciones nacidas de alguna fuente unilateral, como si el deudor gestiona espontáneamente los negocios de su acreedor, con la intención práctica de hacerse su acreedor y compensar, es difícil desencadenar de modo deliberado la compensación legal, porque para hacerlo sobre la base de alguna deuda contractual se requiere la voluntad de la contraparte. Mas, por causa de muerte, atendida la unilateralidad del legado, un acreedor podría desencadenarla si lega bajo forma obligacional congruentemente a su deudor. Supóngase, por ejemplo, al acreedor de 900 que lega 900 a su deudor: tal es un legado ordinario de efecto obligacional, el cual convierte en acreedor al legatario; como al mismo tiempo éste es deudor, tiene lugar la compensación, aunque de diversas maneras dependientes cómo haya pasado el crédito a los herederos del acreedor y de quién haya quedado gravado con el pago del legado. Los casos más simples y extremos son: i) aquel en que el testador dejara un único heredero y nada dispusiera sobre el crédito ni acerca de quién debe cumplir el legado o bien que gravara con éste expresamente a ese heredero, pues entonces tal sería acreedor hereditario y deudor testamentario y habría compensación sin más; ii) aquel en que el testador legara su crédito a alguien y gravara con el pago del legado a otro legatario, caso en el cual no habría compensación en absoluto, porque uno sería el acreedor y otro el deudor. Entremedio las variaciones dependen de la forma de asignar el crédito y de gravar con el legado si hay varios herederos. Por ejemplo, iii) si el testador deja tres herederos y divide el crédito entre ellos y deja gravados a los tres con el pago del legado, como cada heredero se hace acreedor por 300 y deudor por 300 hay tres compensaciones parciales, una entre cada heredero y el legatario. Pero iv) si asigna el crédito a uno de los tres herederos y deja gravados a los tres con el legado, la compensación parcial tendrá lugar únicamente, y sólo por 300, entre el heredero acreedor y el legatario, y no la habrá entre éste y los dos restantes herederos no acreedores; etcétera.

2. En algunos casos, el legado del acreedor al deudor puede tener función remisoria total o parcial por vía de compensación, como en los casos i) y iii), en que la deuda se extingue totalmente, y de una vez o por partes, por compensación; pero es como si el acreedor la hubiera remitido totalmente; $y$, de hecho, en vez de legar aquella suma, hubiera podido remitir la deuda en forma directa; o como en el caso iv), en que la compensación tiene lugar entre el legatario y un heredero, por la parte del legado que gravó a ese heredero al que se le asignó todo el crédito, y es por lo tanto parcial, porque en tal caso es como si el deudor hubiera remitido parcialmente la deuda. Pero no siempre acaece tal fenómeno, por más que se dé una "compensación puramente económica", desde que el deudor recibe un emolumento total o parcialmente equivalente a lo que debe, como en 
el caso ii): aunque el deudor deba pagar su deuda, como también puede cobrar el legado, neutraliza lo pagado con lo recibido, como un efecto puramente económico. Pero verdadera compensación, o sea, en sentido técnico-dogmático, no hubo.

Como siempre acaece con los variados y flexibles recursos que otorgan los legados, la elección concreta de la remisión directa, total o parcial, de la compensación en función remisoria, total o parcial, o de la mera "compensación económica", estará determinada por los fines prácticos cuyo alcance guíe la voluntad del testador.

\section{Confusión con ocasión de un legado.}

Como la compensación, la confusión expuesta en el título $18^{\circ} \mathrm{del}$ libro IV CC. es un efecto del Derecho (artículo 1665 CC.) y no un acto; de donde que ese título esté presidido por una concepción funcional y no estructural. No interesa, en efecto, el origen de las obligaciones que se extinguen debido a que sus calidades polares de acreedor y deudor concurrieron en una misma persona. Tanto si el vendedor sucede al comprador que le había quedado debiendo el precio, como si el que dañó a otro sucede a su víctima a la que le debía la indemnización de perjuicios, y también si el que recibió lo indebido en pago sucede al pagador, en todos los casos la confusión tiene lugar de la misma manera. Lo propio acaece, por ende, si la calidad de acreedor o la de deudor que llegan a coincidir en una misma persona provienen de un legado de efectos obligaciones.

Pero, nuevamente igual que en la compensación, la confusión puede ser desencadenada u ocasionada deliberadamente, aunque, en sí misma, tenga lugar con prescindencia de la voluntad. Entre vivos, la figura puede ser generada si el deudor consigue la cesión del crédito de que es parte pasiva en su favor; lo cual podría convenirle en vez de pagarlo, si lo adquiere de su actual titular (que no tiene por qué ser el acreedor original) a título oneroso, mas por un precio muy inferior a su monto. Por causa de muerte, el efecto se puede desencadenar cuando un testador legara a su deudor el crédito que contra él tiene. Se trata de una lícita aplicación del legado previsto por el artículo 1127 incisos $1^{\circ}$ y $2^{\circ}$ CC. Solo que la preexistente calidad de deudor ofrecida por el legatario empieza a concurrir con la sobreviniente de acreedor a él, y entonces de pleno Derecho tiene lugar la confusión que extingue la deuda, en los términos expuestos en el artículo 1665 CC.; y es como si el acreedor hubiera condonado la deuda a su deudor. Así que esta asignación es, en realidad, una operación compleja que se integra por la estructura de un legado del crédito, la función de condonación y modo de extinguir deudas llamado "confusión". 


\section{PRIMER APÉNDICE: \\ LA INTERPRETACIÓN DEL CONTRATO Y DEL TESTAMENTO}

En esta materia excedemos el tema de los legados para ampliarnos al del testamento, que forma su estructura mayor. Se trata de ver si existe algún paralelismo entre contrato y testamento en tema de interpretación.

La norma básica sobre interpretación del contrato está dada por el artículo 1560 CC.: "Conocida claramente la intención de los contratantes, debe estarse a ella más que a lo literal de las palabras". Pero esta norma es totalmente coincidente con la norma básica de interpretación de las disposiciones testamentarias, contenida en el artículo 1069 CC. Para toda disposición testamentaria, su inciso $1^{\circ}$ hace prevalecer "la voluntad del testador claramente manifestada", incluso por sobre las reglas dadas en el título $4^{\circ}$ del libro III CC. (y, por extensión analógica, por sobre las reglas dadas en cualquier parte del Código); en la medida, por cierto, que dicha voluntad no se oponga a los requisitos o prohibiciones legales. El inciso $2^{\circ}$ de aquel artículo, expresa: "Para conocer la voluntad del testador se estará más a la substancia de las disposiciones que a las palabras de que se haya servido". Esta última dicción equivale a la usada por el artículo 1560 CC.: "más que a lo literal de las palabras". Esto, por cierto, no esconde el hecho básico de que en los contratos se trata de la interpretación de la voluntad común de dos partes, mientras que, en el testamento, de la voluntad de un único autor.

El problema que debemos afrontar es si, pese a esto último, las normas dadas en el título $13^{\circ}$ sobre interpretación del contrato son aplicables a la operación interpretativa del testamento. El punto ha sido tratado por la doctrina chilena; que en general se inclina por la aplicabilidad, en cuanto la naturaleza del testamento -acto esencialmente unilateral- lo permita y la respectiva regla dada en tema de contratos no exija la bilateralidad como supuesto necesario ${ }^{57}$. Pero, a este último respecto, a veces se ha incurrido en excesos, con la negación de la aplicabilidad de algunas reglas dadas para los contratos solo porque la norma habla precisamente de "contrato", sin tomarse razón de que la mención de éste fue determinada por el tema tratado en el título $3^{\circ}$ del libro IV, y sin que, empero, la sustitución de "contrato" por "testamento" esté estructuralmente impedida, de modo que la norma pueda aplicarse con naturalidad a estos últimos por analogía ${ }^{58}$.

${ }^{57}$ Véanse: Domínguez Benavente, R. - Domínguez Águila, R., Derecho sucesorio, cit. (n. 24), I, núm. 338-339, pp. 363-366; Rodríguez Grez, Pablo, Instituciones de Derecho sucesorio (2a edición, Santiago, Editorial Jurídica de Chile, 2002), I, pp. 135-137; Elorriaga De Bonis, Fabián, Derecho sucesorio (Santiago, LexisNexis, 2005), núm. 297, pp. 244-246.

${ }^{58}$ Así, Elorriaga De Bonis, F., Derecho sucesorio, cit. (n. 57), núm. 297, p. 245 , 
A nuestro juicio, sin discusión sólo deben excluirse las siguientes reglas:

i) la del inciso $2^{\circ}$ del artículo 1563 CC., que hace presumir las cláusulas de uso común aunque no se expresen. Tal no se trata de una regla de interpretación, sino, directamente, de una presunción (legal), que, además, concuerda con la exigencia de la buena fe, en orden a que los contratos obligan a aquellas cosas que por la costumbre pertenecen a una obligación. Sólo que ahora no se trata de "cosas" que pertenecen a la "obligación", sino de "cláusulas" que pertenecerían a un testamento; y parece improcedente aceptar que en éstos deban presumirse las cláusulas de uso común, que tendrían que ser cláusulas no de otra naturaleza que testamentaria.

ii) la del artículo 1564 inciso 30: [Podrán también interpretarse] por la aplicación práctica que hayan hecho de ellas [las cláusulas del contrato] ambas partes, o una de las partes con aprobación de la otra", porque ella se funda en que el comportamiento práctico de las partes con respecto a un acto inalterable no puede ser más que interpretativo; mientras que, al trasladar la norma hacia el testamento, que tendría que ser aplicada al comportamiento unilateral de su autor durante su vida después de otorgado aquél, se hace imposible distinguir si ese comportamiento respecto a un acto esencialmente modificable y aún revocable es ejercicio de la facultad de modificar o revocar o resulta meramente interpretativo. Por lo demás, como un testamento está llamado a ser aplicado después de la muerte de su autor, no puede hablarse de su aplicación práctica durante la vida de aquél ${ }^{59}$.

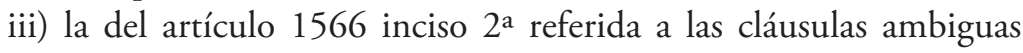

excluye la aplicabilidad del artículo 1563 a la interpretación del testamento, porque ese artículo habla "la naturaleza del contrato" y "ello supone una naturaleza contractual que no está presente en el testamento". Esto es evidente. Pero como también puede hablarse de la "naturaleza de las disposiciones testamentarias", ¿qué impide entender ese artículo como si dijera: "En aquellos casos en que no apareciere voluntad contraria deberá estarse a la interpretación que mejor cuadre con la naturaleza de la disposición testamentaria"?

${ }^{59} \mathrm{Y}$, sin embargo, supóngase la hipótesis de que contendieren dos asignatarios testamentarios, o uno testamentario y cierta persona que se pretende heredera intestada (por lo cual controvierte el testamento), y que del testamento se hubiera hecho alguna aplicación práctica por los litigantes en los términos del citado artículo: esta aplicación, ¿podría ser invocada en contra de alguna de las partes por la otra? Ciertamente una argumentación fundada en la aplicación práctica dada al testamento por alguna de las partes de un juicio, o por ambas, es perfectamente admisible en la dialéctica procesal que lo tenga por objeto de discusión. Pero este comportamiento práctico no vale como interpretación del testamento, porque no fue de su autor, sino de terceros. 
extendidas o dictadas por una de las partes, sea acreedora, sea deudora, que se interpretan contra ella si la ambigüedad proviene de la falta de una explicación que haya debido darse por la misma parte, porque en un testamento, si de exigir explicaciones se trata, ellas sólo fueron exigibles al testador, no a los asignatarios que resulten deudores y acreedores en alguna relación posterior a la apertura del testamento; eso sólo ya hace inaplicable la regla a éste, con independencia de si, en verdad, puede hablarse de exigencia de claridad al testador ${ }^{60}$.

\section{SEGUNDO APÉNDICE: \\ ALGUNOS ACTOS PARALELOS ENTRE VIVOS Y POR CAUSA DE MUERTE QUE NO CONSTITUYEN LEGADOS}

\section{Reconocimiento de hijo.}

De acuerdo con el artículo 187 inciso $1^{\circ}$ CC., el reconocimiento de un hijo como propio consiste en una declaración formulada, con ese determinado objeto, por el padre, la madre o por ambos. Enseguida, en los números que siguen de ese artículo y en el artículo 188 se indica siete formas que puede asumir la declaración de reconocimiento, seis entre vivos ${ }^{61} y$ una por causa de muerte, que denomina “acto testamentario". Con esta manera de hablar, la norma mienta un testamento, en cualesquiera de sus muchas formas válida según el Derecho civil chileno. Atendida la naturaleza estrictamente unilateral de ese acto (artículo 1003 CC.), el reconocimiento testamentario de hijo únicamente puede ser o del padre sólo o de la madre sola, o de ambos, pero en testamentos separados; mientras que entre vivos también puede de ambos conjuntamente.

${ }^{60}$ La regla del artículo 1566 inciso $1^{\circ}$, que, en el caso de no poder aplicarse las reglas dadas en los artículos precedentes, ordena interpretar las cláusulas ambiguas en favor del deudor, no es de interpretación, sino un mandato imperativo de la ley para resolver la duda; y constituye un favor concedido a los deudores, en aplicación expresa de un principio pro debitore. En tales circunstancias, no se ve por qué haya de impedirse su aplicación a los deudores testamentarios, en caso de duda insuperable.

${ }^{61}$ Las formas del artículo 187 CC. son: ante el oficial del Registro Civil (competente) en el momento de inscribirse el nacimiento del hijo (No 1); ante el oficial del Registro Civil (competente) en el acto del matrimonio de los padres (ibíd.); ante cualquier oficial del Registro Civil en un acta extendida en cualquier tiempo (No 2); y en escritura pública (No 4). Las formas del artículo 188 CC., por su lado, son: la indicación del nombre del padre o de la madre en el acta de inscripción de nacimiento del hijo, hecha a petición de cada uno en el momento de la inscripción (inciso 1o); y la confesión de paternidad o de maternidad prestada bajo juramento por el supuesto padre o la supuesta madre, citados a la presencia judicial con tal objeto por el hijo, su representante legal, si aquel es incapaz, o por quien lo tenga a su cuidado (inciso $2^{\circ}$ ). 


\section{Nombramiento de tutor o de curador.}

El artículo 353 CC. establece que hay tres clases de tutelas y curadurías: testamentarias, legítimas y dativas. De las primeras dice que son aquellas constituidas por "acto testamentario"; entiende por legítimas las que se confieren por la ley a los parientes o al cónyuge del pupilo; y por dativas, las que confiere el magistrado. En realidad, de lo que se trata es de la designación del tutor o del curador. En primer lugar, son hábiles para designar tutor a su hijo nacido o por nacer el padre o la madre en su testamento (artículo 354 CC.); y curador al hijo menor adulto, o al hijo adulto que se halle en estado de demencia o que sea sordo o sordomudo que no entiende ni se da a entender claramente (artículo 355 CC.); o que está por nacer (artículo $356 \mathrm{CC}$.). A falta de nombramiento testamentario de tutor o de curador, o habiendo expirado en su cargo el tutor testamentario (si no hay otros de la misma condición o si no tiene tutor sustituto), la ley llama a ciertos parientes del pupilo al ejercicio de su tutela, que por ello se llama legítima. A falta de tutor testamentario y legítimo, el magistrado debe designar al tutor, que se llama dativo.

En consecuencia, nos encontramos ante un especial caso en que la forma por causa muerte prima por sobre la forma entre vivos.

\section{SÍNTESIS}

A los legados, el Código Civil les destina un párrafo en el interior de un título, componente de su libro III ( $\$ 6$, tít. IV, lib. III), en el que van encerrados treinta dos artículos, a los que se añaden disposiciones esparcidas a lo largo del cuerpo legal. Si nos aproximamos a ellos con un punto de vista estructural, de inmediato cobra relieve su carácter de asignación testamentaria que, sin perjuicio de las reglas generales que las rigen, asumen variados tipos que, por lo demás, la misma ley se encarga de describir, generalmente por un elemento estructural también, como es su objeto, de donde resultan los legado de especie (propia y ajena), de género, de cosa futura, legado de cosa indivisa, de opción, de un crédito, de alimentos, etcétera. Y como el Código incluso regula objetos especiales, se avanza hasta distinguir el legado de un carruaje o de un rebaño, etcétera. El punto de vista estructural, que por cierto presta sus servicios, deja en el trasluz, empero, que los legados operan ciertos efectos y ejercen ciertas funciones que no son distintos a los efectos y funciones que se operan y ejercen entre vivos mediante actos generalmente convencionales. Pero cuando se toma cabal cuenta de este paralelismo, se adopta un punto de vista funcional, se comparan los legados y las convenciones para poner de manifiesto precisamente la identidad de muchas funciones que ambos pue- 
den obrar, el panorama que se ofrece al observador cambia radicalmente, porque una parte importante del Derecho patrimonial privado adquiere otro aspecto, precisamente aquel que se configura sobre la base de unos mismos efectos y funciones provenientes de actos de estructura tan diversa como son las convenciones y los legados.

Tal ha sido el propósito de este trabajo, que, por cierto, puede y debe ser completado con nuevos estudios, dirigidos a verificar la existencia de otras funciones comunes a ambos.

[Recibido el 24 de enero y aprobado el 7 de marzo de 2008].

\section{BIBLIOGRAFÍA}

Abeliuk Manasevich, René, Las obligaciones (3a edición, Santiago, Editorial Jurídica de Chile, 1993), dos volúmenes.

Codex Iustinianus (ed. Krüger)

Código Civil de la República de Chile (18 a edición, Santiago, Editorial Jurídica de Chile, 2008).

Código de Aguas (17a edición, Santiago, Editorial Jurídica de Chile, 2007).

Código de Minería (6a edición, Santiago, Editorial Jurídica de Chile, 2008).

Código Orgánico de Tribunales (22a edición, Santiago, Editorial Jurídica de Chile, 2008).

Domínguez Benavente, Ramón - Domínguez Águila, Ramón, Derecho sucesorio (2a edición, Santiago, Editorial Jurídica de Chile, 1998), dos volúmenes.

Elorriaga De Bonis, Fabián, Derecho sucesorio (Santiago, LexisNexis, 2005).

GuZmán Brito, Alejandro, "Dare ob rem", en Caminos romanos. Viae Romanae. Estudios en homenaje a Francisco Samper Polo (Santiago de Chile, Universidad Andrés Bello, 2006), pp. 149-192.

Guzmán Brito, Alejandro, De las donaciones entre vivos. Conceptos y tipos (Santiago, LexisNexis, 2005).

GuZmán Brito, Alejandro, Derecho privado romano ( $1^{\text {a }}$ edición, $3^{a}$ reimpresión, Santiago, Editorial Jurídica de Chile, 2004), dos volúmenes.

Guzmán Brito, Alejandro, El concepto de legado en el Derecho civil chileno, en Revista de Derecho 21 (Universidad Austral de Chile, diciembre de 2008) 2, pp. 53-84.

GuZMÁn BRITO, Alejandro, La doble naturaleza de deuda hereditaria y asignación hereditaria forzosa de los alimentos debidos por ley a ciertas personas, en Revista Chilena de Derecho 35 (2008) 2, pp. 311-339.

Guzmán Brito, Alejandro, La remisión de deudas en el derecho civil, en Revista de Derecho de la Universidad Católica de Valparaíso 13 (Valparaíso, 1989-1990), pp. 51-104; después en El mismo, Estudios dogmáticos de Derecho civil (Valparaíso, Ediciones Universitarias de Valparaíso, 2005), pp. 121-156.

Guzmán Brito, Alejandro, La tipología de los legados en el Derecho civil chileno, en Revista de Derecho de la Pontificia Universidad Católica de Valparaíso 27 (Valparaíso, 2006, Semestre I), pp. 51-85 
GuZMÁn Brito, Alejandro, Las cosas incorporales en la doctrina y en el Derecho positivo (2a edición, Santiago, Editorial Jurídica de Chile, 2006).

Iustiniani Digesta (ed. Mommsen)

Iustiniani Institutiones (ed. Krüger)

Ley $\mathrm{N}^{\circ} 17.336$, sobre propiedad intelectual (DO. 2 oct. 1970).

Ley No 19.030, sobre privilegios industriales y protección de los derechos de propiedad industrial (DO. 25 ene. 1991), modificada por la Ley No 19.996 (DO. 11 mar. 2005).

Ley No 19.585 (DO. de 26 oct. 1998).

Ley No 19.983, sobre la cesión de créditos que constan en facturas (DO. 12 nov. 2004).

Peñailillo, Arévalo, Daniel, Obligaciones. Teoría general y clasificaciones. La resolución por incumplimiento (Santiago, Editorial Jurídica de Chile, 2003).

Rodríguez Grez, Pablo, Instituciones de Derecho sucesorio (2a edición, Santiago, Editorial Jurídica de Chile, 2002), dos volúmenes.

ZANnONi, Eduardo, La buena fe en el derecho sucesorio, en CóRdoba M. (director), Tratado de la buena fe en el Derecho (Buenos Aires, La Ley, 2004), I, pp. 633-637.

Zimatore, Attilio, Il mutuo di scopo. Problemi generali (Padova, Cedam, 1985). 